\title{
An in vitro model for studying CNS white matter: functional properties and experimental approaches [version 1; peer
} review: 2 approved]

\author{
Silvia Bijland ${ }^{1 *}$, Gemma Thomson ${ }^{1 *}$, Matthew Euston ${ }^{1}$, Kyriakos Michail ${ }^{2}$, \\ Katja Thümmler1', Steve Mücklisch1, Colin L. Crawford (D1), Susan C. Barnett (iD1, \\ Mark McLaughlin3, T. James Anderson ${ }^{3}$, Christopher Linington', \\ Euan R. Brown (iD)2, Eric R. Kalkman (iD4, Julia M. Edgar (iD)
}

${ }^{1}$ Institute of Infection, Immunity and Inflammation, College of Medical Veterinary and Life Sciences, University of Glasgow, Glasgow,
G12 8TA, UK
2Institute of Biological Chemistry, Biophysics and Bioengineering, Heriot Watt University, Edinburgh, EH14 4AS, UK
${ }^{3}$ School of Veterinary Medicine, College of Medical Veterinary and Life Sciences, University of Glasgow, Glasgow, G61 1QH, UK
${ }^{4}$ Institute of Cancer Sciences, College of Medical Veterinary and Life Sciences, University of Glasgow, Glasgow, G61 1QH, UK
* Equal contributors

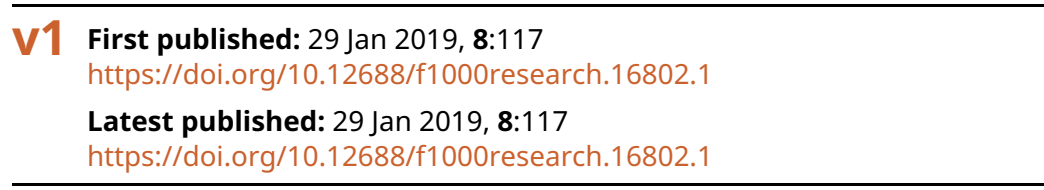

\section{Abstract}

The normal development and maintenance of CNS white matter, and its responses to disease and injury, are defined by synergies between axons, oligodendrocytes, astrocytes and microglia, and further influenced by peripheral components such as the gut microbiome and the endocrine and immune systems. Consequently, mechanistic insights, therapeutic approaches and safety tests rely ultimately on in vivo models and clinical trials. However, in vitro models that replicate the cellular complexity of the CNS can inform these approaches, reducing costs and minimising the use of human material or experimental animals; in line with the principles of the 3Rs. Using electrophysiology, pharmacology, time-lapse imaging, and immunological assays, we demonstrate that murine spinal cordderived myelinating cell cultures recapitulate spinal-like electrical activity and innate CNS immune functions, including responses to disease-relevant myelin debris and pathogen associated molecular patterns (PAMPs). Further, we show they are (i) amenable to siRNA making them suitable for testing gene-silencing strategies; (ii) can be established on microelectrode arrays (MEAs) for electrophysiological studies; and (iii) are compatible with multi-well microplate formats for semi-high throughput screens, maximising information output whilst further reducing animal use. We provide protocols for each of these. Together, these advances increase the utility of this in vitro tool for

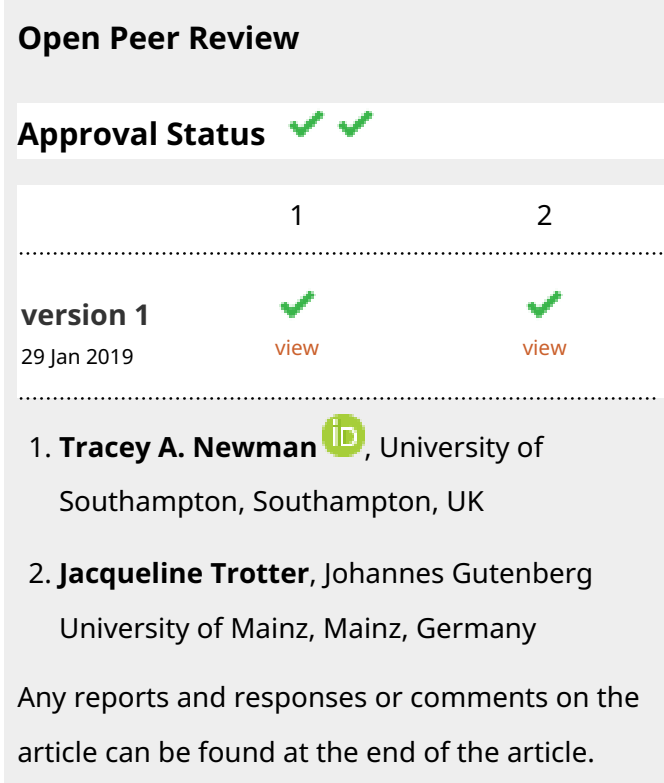


studying normal and pathological development and function of white matter, and for screening therapeutic molecules or gene targets for diseases such as multiple sclerosis, motor neuron disease or spinal cord injury, whilst avoiding in vivo approaches on experimental animals.

\section{Keywords}

(re)myelination, microglia, microelectrode array, semi-high

throughput, spinal cord, siRNA

\section{NC \\ $3 R^{s}$}

This article is included in the NC3Rs gateway.

Corresponding author: Julia M. Edgar (julia.edgar@glasgow.ac.uk)

Author roles: Bijland S: Data Curation, Formal Analysis, Investigation, Methodology, Project Administration, Software, Writing - Original Draft Preparation; Thomson G: Data Curation, Formal Analysis, Investigation, Methodology, Visualization, Writing - Original Draft Preparation; Euston M: Formal Analysis, Methodology, Writing - Review \& Editing; Michail K: Investigation; Thümmler K: Investigation, Software; Mücklisch S: Software; Crawford CL: Investigation; Barnett SC: Supervision; McLaughlin M: Funding Acquisition, Investigation, Supervision; Anderson TJ: Funding Acquisition, Supervision, Writing - Review \& Editing; Linington C: Funding Acquisition, Supervision, Writing - Review \& Editing; Brown ER: Validation, Writing - Review \& Editing; Kalkman ER: Conceptualization, Funding Acquisition, Methodology, Supervision, Writing - Review \& Editing; Edgar JM: Conceptualization, Data Curation, Formal Analysis, Funding Acquisition, Investigation, Methodology, Project Administration, Supervision, Validation, Visualization, Writing - Original Draft Preparation, Writing - Review \& Editing

Competing interests: No competing interests were disclosed.

Grant information: This work was supported by the National Centre for the Replacement, Refinement and Reduction of Animals in Research (NC3Rs) [grant Ref. B004-13.1 to JE, ERK and CL] and the Multiple Sclerosis Society, UK [grant ref. 853 to JE and JTA; grant ref. 918 to JE, MM and JTA; and grant ref. 991 to JE and ERK].

Copyright: @ 2019 Bijland S et al. This is an open access article distributed under the terms of the Creative Commons Attribution License , which permits unrestricted use, distribution, and reproduction in any medium, provided the original work is properly cited. Data associated with the article are available under the terms of the Creative Commons Zero "No rights reserved" data waiver (CC0 1.0 Public domain dedication).

How to cite this article: Bijland S, Thomson G, Euston $\mathrm{M}$ et al. An in vitro model for studying CNS white matter: functional properties and experimental approaches [version 1; peer review: 2 approved] F1000Research 2019, 8:117

https://doi.org/10.12688/f1000research.16802.1

First published: 29 Jan 2019, 8:117 https://doi.org/10.12688/f1000research.16802.1 


\section{Research highlights}

\section{Scientific benefits:}

- Recapitulates in vivo-like myelination, innate immune responses and neuronal electrical activity and is amenable to live cell imaging.

- Compared to single cell type or mixed PNS-CNS cell cultures, this pure CNS multi-cell type system more closely resembles the in vivo situation.

- Uncouples CNS-intrinsic responses from those mediated by peripheral organs and systems.

- Ease of manipulation, i.e. genetic using siRNA; neuronal electrical activity using pharmacological modulators of neural activity; small molecules using small molecule libraries; relevant PAMPs or DAMPS.

- Can be generated from transgenic reporter mice for live imaging and functional readouts or from mutant or transgenic models of disease.

\section{Rs benefits:}

- Inform studies and/or acts as an adjunct to studies using in vivo models of multiple sclerosis, motor neurone disease, the leukodystrophies and other neurodegenerative diseases involving white matter, minimising the use of experimental animals and maximising information obtained.

\section{Practical benefits:}

- Straightforward to establish in any lab with cell culture facilities.

- Compared to CNS slice cultures, which also contain all major neural cell types, this cell culture system is easier to maintain (oxygen and nutrients readily reach all cells) and quicker to set up.

- Cells can be grown on microelectrode arrays that do not require the specialist expertise needed for single cell electrophysiology.

- Cells can be grown on multi-well plates for semi-high throughput assays.

- Multi-well microplate formats facilitate the testing of multiple factors on parallel cultures.

\section{Current applications:}

- Semi-high throughput screens for pro-myelinating or inhibitory factors; testing and verifying siRNA constructs and/or testing the consequences of gene knockdown; modulating neural activity to assess secondary consequences for other cells types; live imaging of cellular interactions.

\section{Potential applications:}

- Semi-high throughput screens for factors that affect axonal survival or regeneration.

- Assessing effects of microglial ablation on other cell types, by manipulating CSF1R signalling pathway.

- Live imaging of organelle distribution and/or transport.

- Initial screen of anti-sense oligonucleotides for gene silencing in the context of in vivo-like cellular phenotypes and morphologies.

\section{Introduction}

Diseases that affect white matter are many and varied, and include spinal cord injury, motor neuron disease, Alzheimer's and multiple sclerosis. Typically, these diseases are modelled and studied in experimental rats and mice, and occasionally in primates, undergoing procedures such as spinal cord contusion, genetic modification or induction of experimental allergic encephalopathy (EAE); procedures that range in severity from moderate to severe under Animals (Scientific Procedures) Act 1986 licensing. Whilst such studies can and do provide important information relevant to human disease, they require careful design and large numbers of animals to provide sufficient power (Baker \& Amor, 2014). For example, we estimate that to test the efficacy of a single drug, 3 cohorts each of 12 animals with EAE is required, depending on effect size and consistency in response (C. Linington, personal communication). Alternative approaches include in vitro techniques, such as human-derived induced pluripotent stem cell models or murine cell cultures.

Indeed, cell and tissue culture is used widely in neuroscience to study the development and function of the major cell types of the CNS; neurons, oligodendroglia, astrocytes and microglia. The main reasons being, in vitro models are a) relatively inexpensive; b) amenable to manipulation, including pharmacological and genetic; c) accessible to live imaging and optogenetic approaches; d) reduce the reliance on experimental animal models for early-stage screening/proof-of-concept studies; and e) inform subsequent animal studies, if they are required. In particular, cell culture assays can reduce the numbers of animal used in in vivo studies by, for example (i) guiding selection of candidate therapeutic molecules, (ii) informing drug dosage concentrations, (iii) measuring toxicity (iv) defining gene targeting efficiency (v) testing gene constructs prior to the generation of transgenic animals.

Single cell type-enriched cultures have been invaluable in addressing questions relating to cell autonomous characteristics (Bechler et al., 2015; Lee et al., 2012a; Mei et al., 2014; Sanchez-Gomez et al., 2018) and simple co-cultures have shed light on bi-cellular interactions (Froger et al., 2010; Lundgaard et al., 2013). However, multi-cell type (Madhavan et al., 2018; Thomson et al., 1993) or explant cultures (Thomson et al., 2006; Zhang et al., 2011) that maintain the complex cellularity and functional properties of the CNS, more closely represent the in vivo situation. As such, they are more relevant for addressing questions where the answer relies on physical interactions and/or paracrine signaling between CNS cell types; notwithstanding they remain uncoupled from the influence of peripheral organs or systems including the gut microbiome, the adaptive immune system and the endrocrine system.

Myelinated nerve fibers are the culmination of complex bidirectional molecular, structural and functional interactions between axons and oligodendrocytes. For example, neuronal electrical activity modulates myelination during development (Demerens et al., 1996; Wake et al., 2011 and reviewed in Almeida, 2018; Almeida \& Lyons, 2017; Zalc \& Fields, 2000) and the myelinating cell supports the myelinated axon throughout life (Edgar et al., 2009; Griffiths et al., 1998; Lappe-Siefke et al., 2003) by modulating axonal transport and the axonal cytoskeleton (Edgar et al., 2004; Kirkpatrick et al., 2001; Pan et al., 2005), maintaining white matter homeostasis (Kassmann et al., 2007; Schirmer et al., 2018) and providing energy substrates 
(Fünfschilling et al., 2012; Lee et al., 2012b; Meyer et al., 2018). Adjacent microglia and astrocytes shape and support the myelinated fiber during development and adulthood (reviewed in Allen \& Lyons, 2018; Thion et al., 2018). For example, microglia clear apoptotic oligodendrocytes generated in excess during development (Barres \& Raff, 1994; Barres et al., 1992), boost developmental myelination by expressing IGF-1 (Wlodarczyk et al., 2017) and remove debris following demyelination or Wallerian degeneration, albeit slowly (George \& Griffin, 1994). Astrocytes secrete factors that enhance developmental myelination (Ishibashi et al., 2006 and reviewed in Barnett \& Linington, 2013), form gap junctions with each other and with oligodendrocytes for exchange of ions and small metabolites (reviewed in Cotrina \& Nedergaard, 2012) and regulate the structure of the mature myelin sheath through secretion of inhibitors of thrombin proteases (Dutta et al., 2018). Conversely, 'activated' microglia and astrocytes can contribute to disease pathogenesis and injury to myelinated fibers, as in mouse models of motor neuron disease (Beers et al., 2006; Boillée et al., 2006; Hall et al., 1998; Nagai et al., 2007; Yamanaka et al., 2008), the leukodystrophies (Ip et al., 2007), and cerebral vascular disease (Fowler et al., 2018). Thus, in vitro models that replicate the interdependence of cells of the intact CNS provide an informative prelude or adjunct to in vivo studies.

We previously described a murine, spinal cord-derived myelinating cell culture system (Thomson et al., 2006; Thomson et al., 2008) to explore axonal organelle distribution (Edgar et al., 2008), cell dynamics (Ioannidou et al., 2012), pro-myelination factors (Berghoff et al., 2017; Goebbels et al., 2017) and neurotropism and pathogenesis of Zika virus infection (Cumberworth et al., 2017). However, little is known about the culture's functional properties with respect to neuronal electrical activity or innate immune responses; factors that influence normal development as well as pathology. Further, the possibility of modifying it for use as an electrophysiological or gene silencing assay has not been explored. Here we validate this system as a functional model of CNS white matter, and describe adaptations to increase its utility in the study of development and disease. This model is straightforward to establish in any laboratory with basic cell culture facilities, and its use can be extended as described here, if equipment is available for live imaging, microelectrode array and/or multi-well plate microscopy.

\section{Methods}

Mice

All animals were bred and maintained in conventional caging, with up to 4 cage companions, in the Biological Services Facilities (BSF) at the University of Glasgow; $12 \mathrm{~h}$ light-dark cycle and food and water ad libitum. Bedding was non-sterile wood-chip; food was normal maintenance diet; water was normal tap water; temperature was $19-21{ }^{\circ} \mathrm{C}$; and humidity was $55 \% \pm 10 \%$. Environmental enrichment took the form of minitubes, sizzle nest and burrowing treats (sunflower and pumpkin seeds). The mice themselves were not health-screened but the BSF was free of the major rodent pathogens but positive for some adventitious agents, namely - for the period in question pinworms, Helicobacter spp., Pasteurella pneumotropica and Mouse Norovirus. Embryonic day 13 (E13; day of plug being E0) mice (of both sexes; sex undetermined) were obtained by time mating wild type mice; $\mathrm{Cnp}^{+/+}$with $\mathrm{Cnp}^{-{ }^{--}}$mice (Lappe-Siefke et al., 2003), both on a C57BL/6J (Charles River) background; or wild type females with hemizygous Thyl-CFP males (Feng et al., 2000), both on a C57BL/6N (Charles River) background. Pregnant dams were killed on the morning of E13 by cervical dislocation followed by decapitation and the uterine horns containing the developing embryos were removed after laparotomy, and immediately placed on ice in a sterile $10 \mathrm{~cm}$ Petri dish. Adult (postnatal day [P] 60 - P120, male and female homozygous Plp1 transgenic (line \#72; (Readhead et al., 1994) and wild type mice (littermates or closely related mice from the same colony) were killed in gradually increasing levels of $\mathrm{CO}_{2}$, followed by decapitation, and the spinal cord was extracted rapidly for preparation of a myelin-enriched tissue fraction. All animal use was approved by the Ethical Committee of the University of Glasgow and licensed under the Animal [Scientific Procedures] Act 1986 project licence PPL60/3656. Experiments on animal-derived cell cultures were conducted according to ARRIVE guidelines, including randomisation of samples in multi-well microplates, blinding of the experimenter and/or automation of quantification, as indicated. Numbers of technical repeats and independent biological repeats are indicated in the Figure Legends. Technical repeat: independent wells/dishes from a single cell culture. Biological repeat (or experimental unit): independent cell culture, generated by pooling all embryos from a single pregnant mouse.

Plpl tg mice $\geq 3$ months of age mice are prone to seizures. Mice appearing dull or apathetic (suggesting a post-ictal problem) or which has an observed seizure lasting more than 2 minutes were killed by a humane method. In the vast majority of instances, the mice were used prior to the development of seizures.

\section{Myelinating cell cultures}

A step-by-step protocol is provided in the supplementary protocol document (Supplementary File 1). The procedure for preparing murine myelinating cultures described (Thomson et al., 2008) was modified slightly. Briefly, E13.5 mouse spinal cords were dissected, then incubated in $1 \mathrm{ml}$ per 6 cords of $0.25 \%$ trypsin in HBSS minus calcium and magnesium for 15 minutes at $37^{\circ} \mathrm{C}$. The digestion was stopped using $1 \mathrm{ml}$ per 6 cords SD solution (Thomson et al., 2008) or Plating Medium (PM; 50\% DMEM, $25 \%$ HBSS and $25 \%$ horse serum) plus $0.04 \mathrm{mg} / \mathrm{ml}$ DNase (or more, if required). The cells were triturated, resuspended in PM and plated on coverslips ( $3 \times 13 \mathrm{~mm}$ diameter per $35 \mathrm{~mm}$ Petri dish), imaging dishes or microelectrode arrays (MEAs) at $\sim 150,000$ cells per $100 \mu \mathrm{lPM}$, per $133 \mathrm{~mm}^{2}$; or in 96 or 384-well dishes in $50 \mu \mathrm{l}$ PM, at various concentrations (see Results). From day in vitro (DIV) 0 , cells were grown in 50\% PM and 50\% differentiation medium (DMEM supplemented with $30 \%$ D-glucose (4500 mg/l glucose final), $10 \mathrm{ng} / \mathrm{ml}$ biotin, $50 \mathrm{nM}$ hydrocortisone, $10 \mu \mathrm{g} / \mathrm{ml}$ insulin, $0.5 \%$ hormone mix (stock concentration $1 \mathrm{mg} / \mathrm{ml}$ apo-transferrin, $20 \mathrm{mM}$ putrescine, $4 \mu \mathrm{M}$ progesterone, and $6 \mu \mathrm{M}$ selenium; based on (Bottenstein \& Sato, 1979), at $37^{\circ} \mathrm{C}$ in 5 or $7 \% \mathrm{CO}_{2}$, then fed three times a week by replacing half the medium with serum-free differentiation media. All DMEM contained $100 \mathrm{U} / \mathrm{ml}$ penicillin and $100 \mu \mathrm{g} / \mathrm{ml}$ streptomycin. From DIV 12 onwards, feeding was done with 
insulin-free differentiation media. The effect of Activin-A (AA; R\&D Systems, Cat. 338-AC-010; Lot BNV3313053) and recombinant human fibroblast growth factor 9 (FGF9; R\&D Systems, Cat. 273-F9-025; Lot ON1413121 or ON1413041) on myelinating cultures was investigated between 15 (AA) or 18 (FGF9) and 28 DIV, on cells grown on multi-well microplates. For treating with 'myelin debris', coverslips were transferred from $35 \mathrm{~mm}$ Petri dishes the day before, into 24 well dishes in maximum $500 \mu$ differentiation media.

\section{Treatment of cell grown on multi-well microplates}

To minimise 'edge-effects' due to increased rate of evaporation or warming of media, cells were not plated in the wells on the outer edges of the microplate. Instead, these were filled with Hank's Balanced Salts solution. DMSO (1\% v/v), AA (1-100 ng ml-1) or FGF9 (100 $\mathrm{ng} \mathrm{ml}^{-1}$ were added to wells following a pre-generated random pattern that varied from one experimental repeat to the next, to avoid potential effects related to the location of the wells on the microplates.

\section{Live imaging dishes}

A protocol for custom made imaging dishes is described in the supplementary protocol document (Supplementary File 2). Briefly, 3 x $11 \mathrm{~mm}$ diameter holes were burred in the bottom of $35 \mathrm{~mm}$ Petri-dishes (Falcon Ref. 353001) and $25 \mathrm{~mm}$ diameter glass coverslips (Menzel-Glaser 0,17 +/- 0,01 mm; Starke 1,5; Lot \#004710182; Thermo Scientific) were stuck to the base of the dishes using non-toxic glue. Dishes are cleaned and sterilised then coated with poly-L-lysine. Live imaging dishes were alternatively purchased from MatTek Corporation, Ashland, USA or custom made (Kline, 2009).

\section{Substrates for cell adhesion}

Poly-L-lysine (PLL; $13.3 \mu \mathrm{g} / \mathrm{ml}$ ) in water or boric acid buffer (50 $\mathrm{mM}$ boric acid, $23.5 \mathrm{mM}$ sodium tetraborate, $\mathrm{pH}$ 8.5) was used to coat $13 \mathrm{~mm}$ diameter glass coverslips (Fisher Scientific, Leicestershire; 631-0150), imaging dishes, microelectrode arrays or microplates (96 [Greiner 655891] or 384-well [Greiner 781856] Sensoplate Plus, black, $175 \mu \mathrm{M}$ glass bottom, Greiner Bio-One) for $1-12$ hours at $37^{\circ} \mathrm{C}$, after which the PLL was aspirated, the glass washed three times in $\mathrm{dH}_{2} \mathrm{O}$ and air dried in the laminar flow hood. Empirically, we found the cultures were far less reproducible if PLL was prepared in water compared to boric acid buffer.

\section{Myelin isolation from mouse spinal cord}

A step-by-step protocol is provided in the supplementary protocol document (Supplementary File 3). Adult (P45-P120) wild type or Plpl transgenic mice were killed in gradually increasing levels of $\mathrm{CO}_{2}$ and the spinal column was severed at the lumbar and cervical regions. The spinal cord was rapidly removed by introducing sterile saline under pressure to the lumbar region of the spinal canal, using an 18-gauge hypodermic needle attached to a $5 \mathrm{ml}$ syringe. Cords were immediately processed or snap-frozen and stored in liquid nitrogen. Myelin was harvested following the method of (Norton \& Poduslo, 1973), with slight modification. All steps were performed at $4^{\circ} \mathrm{C}$, using filter sterilised solutions prepared from cell culture grade diluents or MilliQ water. Cords were homogenised in sterile $0.85 \mathrm{M}$ sucrose solution in
$10 \mathrm{mM}$ HEPES using a polytron homogeniser at full speed for 12 strokes. Three $\mathrm{ml}$ of a $0.25 \mathrm{M}$ sterile sucrose solution in $10 \mathrm{mM}$ HEPES was slowly added on top of $7.5 \mathrm{ml}$ of the homogenate. The samples were spun at $70,000 \mathrm{x}$ g for 90 minutes at $4{ }^{\circ} \mathrm{C}$ in a Beckman SW41 rotor. The interface between the sucrose layers, containing the membrane fractions, was gently aspirated and washed by vortexing in $6 \mathrm{ml}$ chilled MilliQ water then spun at $23,000 \mathrm{x} g$ for 30 minutes in a Beckman $\mathrm{J} 21$ rotor, to remove the excess sucrose. This osmotic shock was repeated twice more. Following a final $19,000 \mathrm{x} \mathrm{g}$ spin, the resultant myelin-enriched pellet was resuspended in cell culture grade phosphate buffered saline (PBS; Sigma-Aldrich, catalogue number 806552). The protein concentration was measured using Pierce BCA protein assay kit (Thermo Fisher Scientific, catalogue number 23225) and this myelin fraction was tested for sterility (by incubating a sample in cell culture media at $37^{\circ} \mathrm{C}$ for 7 days), and labeled with NHS-Rhodamine Antibody Labeling Kit (Thermo Fisher Scientific, product \#53031), according to the manufacturer's instructions.

Addition of exogenous myelin to myelinating cell cultures A rhodamine-labeled myelin enriched tissue fraction $(2 \mathrm{mg}$ protein $\mathrm{ml}^{-1}$ myelin homogenate) was added to the myelinating cultures at DIV 21, DIV 25 or DIV 27 (all \pm 1 day), to a final concentration of 0.075 or $0.1 \mathrm{mg}$ protein $\mathrm{ml}^{-1}$ (unless otherwise indicated) for respectively, 7, 3 or 1 DIV. Cell culture grade PBS alone (to the same volume as the myelin emulsion), or $3 \times 10^{6}$ one $\mu \mathrm{m}$ diameter Flurobite fluorescently labeled latex beads (Polyscience, Park scientific, Northampton, UK) were added in parallel. Two coverslips, each plated at the start with 150,000 spinal cord cells, were treated with wild type myelin, Plp1 tg myelin, PBS or latex beads. Cells were fixed and stained with rat anti-CD45 (Serotec, catalogue number MCA 1388, monoclonal; 1 in 600) to label microglia at DIV 28 ( \pm 1 day) for analysis. Independent myelin preparations were used for each experimental repeat.

\section{Antibodies and immunocytochemistry}

A supplementary protocol document is attached (Supplementary File 4). In general, cell cultures were fixed with $4 \%$ paraformaldehyde for 10-20 min at room temperature (RT), washed in PBS, permeabilized in $0.5 \%$ Triton $\mathrm{X}-100 / \mathrm{PBS}$ for $15 \mathrm{~min}$ at RT or in methanol for 10 minutes $-20^{\circ} \mathrm{C}$, washed with PBS, and blocked with $1 \%$ BSA/10\% horse serum/PBS or with $10 \%$ goat serum/PBS for 1 hour at RT. Primary antibodies used were: rat anti-MBP (MCA4095; 1:500); rat anti-CD45 (MCA 1388; 1:300); rat anti-mouse CD68 (MCA1957T; 1:200; all Serotec Ltd, Oxford, UK), mouse anti-CNP (SMI191; 1:1000) and rat anti CD11b (Biolegend 101205 1:50; both Cambridge Bioscience, Cambridge, UK), SMI31 mouse antibody to phosphorylated neurofilament (1:1500; Affiniti Research Products Ltd., Derbyshire, UK), rabbit anti-Caspr (1:1000; kindly provided by Professor E. Peles), rabbit anti-green fluorescent protein (ab6556; 1:1000; Abcam, Cambridge, UK), rat anti-lysosome-associated membrane glycoprotein 1 (1D4B; 1:2 Developmental Studies Hybridoma Bank, Iowa, U.S.A.), mouse anti-myelin oligodendrocyte glycoprotein, (1:200, clone Z2 provided by C. Linington), rabbit anti-ionized calcium binding adapter molecule 1 (Iba1; 019-19741; 1:800, Wako, Neuss, Germany). These were diluted 
in blocking buffer and incubations performed at RT for 1 hour or overnight at $4^{\circ} \mathrm{C}$. Anti-CD45 worked best on acetone fixed cells $\left(10 \mathrm{mins},-20^{\circ} \mathrm{C}\right)$. Bound antibodies were visualised using appropriate combinations of species/isotype-specific fluorochrome-conjugated secondary antibodies (1:400 [or in later experiments, 1:1000] 488 goat-anti mouse IgG1, catalogue number A2112; 568 goat anti-mouse $\mathrm{IgG1}$, catalogue number A21124; 488 goat-anti-rat IgG, catalogue number A11006; 568 goat anti-rat IgG, catalogue number A11077; 488 goat-anti rabbit IgG, catalogue number A11008; 568 goat anti-rabbit IgG, catalogue number A11036; all Alexa Fluor, Life Technologies) after incubation at RT for 15-60 minutes. Nuclei were stained with DAPI $(2 \mu \mathrm{g} / \mathrm{ml})$ for 5 minutes, then wells of the multi-well microplates were filled with $100 \mu \mathrm{l}$ PBS (although Mowiol also works well, and solidifies). Coverslips were mounted on glass slides in Citifluor AF1 mounting medium (Agar Scientific, Essex, UK, catalogue number AGR1320) or Mowiol 4-88 prepared as described in the supplementary protocol document, by dissolving 2.4 g Mowiol 4-88 (\#81381, Sigma-Aldrich) in $6.0 \mathrm{~g}$ analytical grade glycerol, $6 \mathrm{ml}$ distilled water, $12 \mathrm{ml} 0.2 \mathrm{M}$ Tris pH 8.5. Plates were imaged on an IN Cell Analyzer 2000 (GE Healthcare) and coverslips were imaged using wide-field fluorescence microscopy.

\section{Image Acquisition in Cell Analyzer}

The IN Cell Analyzer 2000 (GE Healthcare) was used to acquire multiplexed wide-field fluorescent images in 96-well microplate format with a Nikon 10X 0.45NA Plan Apo objective, with the following channels 490/20 nm \& 525/36 nm (green), 579/24 $\mathrm{nm} \& 624 / 40 \mathrm{~nm}$ (red) and 350/50 nm \& 455/50 nm (DAPI). Using these three channels, six fields of view were imaged per well. Flat Field Correction (illumination correction) was used as an image pre-processing step during image acquisition. Axonal density (area stained with antibody SMI31, antineurofilament), myelin (area stained with anti-MOG or anti-MBP) and cell counts (number DAPI +ve nuclei) were quantified using CellProfiler image analysis software version 2.1.0 (Carpenter et al., 2006). The pipelines developed for this study are available from GitHub. A supplementary protocol document is attached (Supplementary File 5). Briefly, images were coded with parental metadata (imageID, wellID) and also with row/ column metadata. Quality control of the images was based on cell numbers, axon density and artefacts. Nuclei were identified in the DAPI image as primary objects after image thresholding using the Otsu global method. Shape was used to segment closely spaced cell. Images with less than 1500 nuclei/image were not used for subsequent analyses. Axonal density was measured in the red image (SMI31) after global thresholding using the Otsu, three classes weighted variance method. Total area occupied by phosphorylated neurofilament was measured and image sets with less than $40 \%$ 'axonal density' were not used for subsequent analyses. In the green channel (MBP), after applying an Otsu global threshold, myelin-like sheaths were identified using compactness $\geq 2.5$ and form factor $\leq 0.2$. Nuclei count, total area, axon area and myelin area measurements were exported to a comma-delimited spreadsheet for data analysis. The average value obtained from all images from each of the treatment conditions, from a single independent cell culture, were considered one independent experimental unit, unless otherwise stated in the Figure legends.

\section{Wide-field fluorescence microscopy}

To quantify cellular parameters in myelin treated cultures, 10 images (selected at random on the blue [DAPI] channel) each of the green (CD45), red (rhodamine-labelled myelin) and blue channels were captured using a x20 objective over two $13 \mathrm{~mm}$ cover slips per condition, for each independent experiment, using a CCD camera system (Photonic Science Colour Coolview) and ImagePro 6.0 software (Media Cybernatics, Silver Spring MD). To calculate CD45 +ve cell density, manual counts of CD45 positive cells containing a DAPI-labelled nucleus were made from each image within an AOI of $124384 \mu \mathrm{m}^{2}$ and the sum of the values were converted to cells per $\mathrm{mm}^{2}$. To quantify myelin uptake, the number of CD45 +ve cells containing rhodaminelabelled myelin per AOI was expressed as a percentage of all CD45 +ve cells per AOI. The experimenter was blinded to the 'genotype' of the myelin during cell quantification. Immunostained cultures were also imaged on a Zeiss Axioimager M2 wide-field microscope with Zen 2012 (Blue Edition) version 1.1.2.0 software.

\section{Cytokine arrays}

Cytokine arrays were used to provide semi-quantitative data on cytokines and chemokines produced in response to damage and pathogen associated molecular patterns. Cultures were incubated with cell culture grade PBS, myelin of either genotype in PBS (0.1 mg myelin-protein $\mathrm{ml}^{-1}$ final concentration), or LPS (100 ng ml ${ }^{-1}$; E-coli mutant O111:B4; VWR). One ml conditioned media (CM) was collected at DIV 27, spun at $12470 \mathrm{~g}$ for 1 minute and the upper $800 \mu \mathrm{l}$ was stored at $-80^{\circ} \mathrm{C}$ until required. Semi-quantitative analysis of cytokine/chemokine levels was performed using Proteome Profiler ${ }^{\mathrm{TM}}$ Array, Mouse Cytokine Array Panel A (ARY006; R\&D Systems Europe Ltd., Abingdon, $\mathrm{UK}$ ), according to manufacturer's instructions. Briefly, nitrocellulose membranes, containing 40 anti-cytokine antibodies in duplicate, were blocked in $2 \mathrm{ml}$ of blocking buffer (array buffer 6) on a rotating platform for one hour. CM from matched samples were probed in parallel. Eight hundred $\mu \mathrm{CM}$ was added to $0.5 \mathrm{ml}$ of array buffer 4 and then adjusted to $1.5 \mathrm{ml}$ with array buffer 5. Fifteen $\mu \mathrm{l}$ of reconstituted Cytokine Array Panel A detection antibody cocktail, containing biotinylated antibodies, was added to each CM sample, for $1 \mathrm{~h}$ RT. After removal of array buffer 6 , the 4 nitrocellulose membranes ( 1 per condition) were incubated in the sample/antibody mixture overnight at $4^{\circ} \mathrm{C}$. Membranes were incubated in $1.5 \mathrm{ml}$ of streptavidin-HRP (in Array Buffer 5) for $30 \mathrm{~m}$ at RT then treated with Pierce enhanced chemiluminescence western blotting substrate catalogue number 32106 (Perbio Science UK Ltd., Cramblington, UK) and subsequently exposed to X-ray film for between 1 and $20 \mathrm{~min}$ utes. X-ray films were scanned and made into digital images and the volume of each spot (minus the average edge volume) was quantified using array analysis software (TotalLab TL100 Array v2008; Newcastle upon Tyne, UK). For each membrane, the signal volume of each of two paired spots (representing a single cytokine) was normalised to the average spot volume of 6 positive control spots on the same membrane, and the average value of the paired spots, as a percentage of the control spot value, was derived. This method corrected for different incubations and/or exposures across different independent experiments. The experimenter was not blinded during this experiment or its analysis, but the automated quantification prevented experimenter 
bias. Medium from each of the four conditions, from a single independent cell culture, was considered one experimental unit.

\section{Electrophysiology}

Dissociated E13 spinal cord cells were established on MEAs (60MEA200/30iR-Ti-gr; Multi Channel Systems, Reutlingen, Germany) as described in 'Myelinating Cell Cultures'. Electrophysiological recordings were performed from DIV 20-30. Sixteen channels were read simultaneously at $37^{\circ} \mathrm{C}$ in differentiation medium, in a custom-built laboratory MEA holder connected to a 16-channel amplifier (A-M Systems; Washington, USA). The array was subsequently rotated in the holder in order to read from all channels. Three minutes of extracellular recording were collected per channel (High Pass: $3 \mathrm{~Hz}$; Low Pass: $500 \mathrm{~Hz}$, Gain 20 k; Notch On). A semi-permeable membrane (fluorinated ethylene-propylene) was placed on top of the array, allowing cultures to be returned to the incubator and recordings to be made on subsequent days. Acquired data were analysed off-line. Modulators of neural activity were added directly to the bath: tetrodotoxin (TTX; $1 \mu \mathrm{M}$; Tocris Cat. 1069), cyanquixaline (CNQX; $5 \mu \mathrm{M}$; Tocris Cat. 1090), picrotoxin (100 $\mu \mathrm{M}$, SigmaAldrich, Cat. P1675).

For single cell recording, whole-cell current clamp recording was performed using an Axopatch 200B amplifier with a Digidata 1440A digital acquisition system and pClamp 10 software. Experiments were performed at $37^{\circ} \mathrm{C}$ in atmospheric $\mathrm{CO}_{2}$ using an extracellular solution containing identical ionic concentrations to the cell culture media (in $\mathrm{mM}$ ): $110.3 \mathrm{NaCl}, 5.3 \mathrm{KCl}$, $1.8 \mathrm{CaCl}_{2}, 0.8 \mathrm{MgCl}_{2}, 10$ HEPES, 25 glucose, $\mathrm{pH}$ 7.4. The pipette solution contained (in $\mathrm{mM}$ ): $135 \mathrm{~K}$-gluconate, $2 \mathrm{MgCl}_{2}, 2 \mathrm{Na}$ ATP, 0.5 Na-GTP, 10 HEPES, 0.5 EGTA, pH 7.2. Borosilicate glass pipettes were pulled to a resistance of 3-8 M $\Omega$. TTX and other modulators (see above) were added directly to the tissue chamber.

\section{Live imaging of myelin phagocytosis}

Spinal cord cells were plated on $35 \mathrm{~mm}$ diameter glass bottom Petri dishes (mentioned previously) and cultured for 20-22 days. Immediately prior to imaging, rhodamine-labelled myelin was vortexed and added to the Petri dish at final concentration $0.05 \mathrm{mg}$ myelin-protein $\mathrm{ml}^{-1}$. The dish was set in a Nikon TE 2000 time-lapse microscope inside a temperature $/ \mathrm{CO}_{2}$-controlled chamber. Using Metamorph 7.5.2 imaging software set for multi-stage positions and multiple wavelengths, positions of interest were selected on the bright field (phase), cherry (rhodamine) and CFP channels, and the co-ordinates recorded. Focus was set and maintained using a PSF perfect focus control. Images were taken every 15 minutes over a $15 \mathrm{~h}$ period. AVI videos of the stills collected were then generated using ImageJ 1.44 software.

\section{Western blotting}

Cell lysates from siRNA studies or spinal cord homogenates were prepared to $1 \mathrm{mg}$ protein $\mathrm{ml}^{-1}$ in RIPA lysis buffer system with protease inhibitors (sc24948; Insight Biotechnology), plus $5 \mathrm{x}$ loading buffer (Sodium dodecyl sulphate/Dithiothreitol denaturing buffer [SDS/DTT]), and heated to $65^{\circ} \mathrm{C}$ for ten minutes. Lysates (see Table 1 for protein amounts) were run on a $4-12 \%$ gradient NuPAGE bis-tris acrylamide gel (Invitrogen, Paisley,
UK) at 200 volts for 40-50 minutes and transferred using a semi-dry system to a PVDF membrane (Millipore, Watford, UK) at $225 \mathrm{~mA}$ for $1 \mathrm{~h}$ per 2 gels. PVDF membranes were blocked in 5\% milk in Tris-buffered saline/ $0.01 \%$ tween (TBS/T; $\mathrm{pH}$ 7.4) and incubated overnight with primary antibody (Table 1) in blocking solution at $4{ }^{\circ} \mathrm{C}$, with gentle agitation. Following thorough washing, membranes were incubated in horseradish peroxidase (HRP)-conjugated goat anti-mouse or goat anti-rabbit secondary antibodies (New England Biolabs, Dundee, UK) in blocking solution (Table 1) for $1 \mathrm{~h}$ RT. Following thorough washing and incubation in Pierce enhanced chemiluminescence western blotting substrate (Thermo Fisher Scientific, catalogue number 32106)), the PVDF membrane was exposed to x-ray film (AGFA) for $30 \mathrm{sec}$ to $20 \mathrm{~min}$ to obtain optimal exposures.

SiRNA

Dharmacon's Accell siRNA passive delivery system including 'smart pool' siRNA (Perbio Scientific) for "difficult to transfect cells" (Mir \& Le Breton, 2008; Shen et al., 2008), was used. Qualitative assessment indicated that cultures incubated in Accell DM supplemented with biotin (10 $\mathrm{ng} / \mathrm{ml}$ final) and D-glucose (4500 $\mu \mathrm{g} / \mathrm{ml}$ final) (referred to as Accell $\mathrm{DM}^{+}$), fared better than cells incubated in Accell DM alone, therefore siRNA was routinely added to the cultures in $\mathrm{DM}^{+}$. At DIV 20, cultures were treated with (i) Accell $\mathrm{DM}^{+}$(ii) $1 \mu \mathrm{M}$ non-targeting (NT) siRNA, (iii) $1 \mu \mathrm{M} C y B$ siRNA or (iv) $1 \mu \mathrm{M} C n p 1$ siRNA (all 'smart pool') in Accell $\mathrm{DM}^{+}$for 72 hours between DIV 20-23 and for a further 72 hours, between DIV 28-31. Between incubations with siRNA, cultures were fed as usual with differentiation media minus insulin. Cell lysate from each of the five conditions, from a single independent cell culture, was considered one experimental unit.

\section{Statistics}

Statistical analyses were made using GraphPad Prism versions 5.0, 6.0 or 7.0 for Windows (GraphPad Prism Software, San Diego, USA). Significance levels were set to $\mathrm{p}<0.05$. One-way ANOVA using Bonferroni's Multiple Comparison Test was used to determine effects of siRNA, comparing all conditions to NT siRNA. For analysis of myelin uptake by CD45+ve cells between genotypes and across time points, a two-way ANOVA followed by Tukey's multiple comparisons test was used. For analysis of steady state levels of 40 cytokines on proteome arrays, 'multiple Student's t tests' were used to compare between myelin genotypes or between myelin genotype and PBS. Unless otherwise indicated, each $\mathrm{n}$ value derives from a single independent cell culture, comprising multiple wells or coverslips, representing technical replicates of the various treatments. In general, statistically tested experiments were carried out on 3-5 independent cell cultures, usually comprising 2 or more technical repeats (as indicated in Figure Legends or text). Up to 7 cultures per protein were examined by western blotting following treatment with siRNA, due to variation in the arbitrary units' values from experiment to experiment.

\section{Results}

Spinal cord-derived cell cultures recapitulate functional properties of CNS white matter

The function and structure of CNS white matter is dependent on a complex interplay between axons, oligodendrocytes, astrocytes 
Table 1. Antibody and lysate details for western blots.

\begin{tabular}{|c|c|c|c|c|c|c|c|c|}
\hline & Supplier & Cat. No. & Host & $\begin{array}{l}\text { Approx. Mol } \\
\text { weight }\end{array}$ & $1^{\circ} \mathrm{ab}$ & $2^{\circ} a b$ & Cell Lysate & $\begin{array}{l}\text { Spinal Cord } \\
\text { Lysate }\end{array}$ \\
\hline GAPDH & Abcam & Ab9845 & Rabbit & $40 \mathrm{kDa}$ & 1 in $1 k$ & 1 in $5 k$ & $5 \mu g$ & $5 \mu \mathrm{g}$ \\
\hline CNP & Cambridge Bioscience & SMI-91R500 & Mouse IgG1 & 46 and $48 \mathrm{kDa}$ & 1 in $5 k$ & 1 in $2 k$ & $20 \mu \mathrm{g}$ & $5 \mu \mathrm{g}$ \\
\hline$\beta$ Actin & Sigma-Aldrich & A1978 & Mouse IgG1 & $43 \mathrm{kDa}$ & 1 in $1 k$ & 1 in $5 k$ & $5 \mu \mathrm{g}$ & $5 \mu \mathrm{g}$ \\
\hline $\begin{array}{l}226 \text { (PLP } \\
\text { /DM20) }\end{array}$ & N.P Groome & & Rabbit & $27 \mathrm{kDa}$ & 1 in $50 \mathrm{k}$ & 1 in $5 k$ & $20 \mu g$ & $2 \mu g$ \\
\hline MAG 248 & N.P Groome & & Rabbit & $100 \mathrm{kDa}$ & 1 in $1 k$ & 1 in $5 k$ & $20 \mu \mathrm{g}$ & $5 \mu \mathrm{g}$ \\
\hline Mitofusin 2 & Sigma-Aldrich & M6319 & Rabbit & $86 \mathrm{kDa}$ & 1 in $1 k$ & 1 in $5 k$ & $20 \mu \mathrm{g}$ & $5 \mu \mathrm{g}$ \\
\hline OPA1 & GeneTex & GTX129917 & Rabbit & 112 kDa & 1 in $1 k$ & 1 in $5 k$ & $20 \mu \mathrm{g}$ & \\
\hline NF160 & Sigma-Aldrich & N2787 & Mouse IgG1 & 160 kDa & $1 \mathrm{in} 100 \mathrm{k}$ & 1 in $10 \mathrm{k}$ & $20 \mu \mathrm{g}$ & $2 \mu \mathrm{g}$ \\
\hline SMI31 & $\begin{array}{l}\text { Affiniti Research } \\
\text { Products Ltd }\end{array}$ & SMI 31P & Mouse IgG1 & $>200$ kDa & 1 in $100 \mathrm{k}$ & 1 in $10 \mathrm{k}$ & $20 \mu \mathrm{g}$ & $2 \mu \mathrm{g}$ \\
\hline Parkin & Santa Cruz & sc-32282 & Mouse IgG2b & $52 \mathrm{kDa}$ & 1 in 500 & 1 in $5 k$ & $20 \mu \mathrm{g}$ & \\
\hline Cyclophilin B & Abcam & ab178397 & Rabbit & $21 \mathrm{kDa}$ & 1 in $1 k$ & 1 in $10 \mathrm{k}$ & $5 \mu \mathrm{g}$ & $5 \mu \mathrm{g}$ \\
\hline Ac. tubulin & Sigma-Aldrich & T7451 & Mouse IgG2b & $55 \mathrm{kDa}$ & 1 in $1 k$ & $1 \mathrm{in} 10 \mathrm{k}$ & $1 \mu g$ & $5 \mu \mathrm{g}$ \\
\hline Ty. tubulin & Sigma-Aldrich & T9028 & Mouse IgG3 & $55 \mathrm{kDa}$ & $1 \mathrm{in} 1 \mathrm{k}$ & $1 \mathrm{in} 10 \mathrm{k}$ & $1 \mu g$ & $5 \mu g$ \\
\hline
\end{tabular}

and microglia; including physical, metabolic, receptor-dependent signaling and gap junction-mediated cell-to-cell communication. Myelinated cultures derived from E13 mouse spinal cord, recapitulate this cellular complexity (Figure 1A-E), and by day in vitro (DIV) 24-28, comprise consecutive myelinated internodes separated by nodes of Ranvier (Figure 1F). To define this system in terms of function, we began by examining its electrical properties using microelectrode arrays (MEAs) (Figure 2A), each comprising 59 recording electrodes. The recordings obtained at a single electrode represent the combined extracellular responses of neurons and glia. Recordings taken daily between DIV 20 and 24, when myelination is occurring, demonstrated the gradual changes in electrical activity, starting with single isolated spikes and progressing to burst-like activity (Figure 2B). Additive pharmacology (sequential administration of drugs without washout) demonstrated distinct 'network-like' aspects of the neuronal activity (Figure 2C), not unlike the fictive bursting activity seen in isolated intact spinal cord segments (Grillner et al., 1981). Picrotoxin, a GABAergic inhibitor, evoked enhanced firing (second versus first trace) and subsequent addition of TTX (a voltage-gated $\mathrm{Na}^{+}$channel blocker) blocked spike-like (presumably axonal) activity, whilst CNQX (blocker of AMPA/ kainate receptors) further blocked (presumably) excitatory postsynaptic activity. The remaining slow potential changes (final trace) probably represent local spontaneous depolarizations at neuronal cell bodies and dendrites. To provide support for these conclusions we used single cell patch clamp recording. Spontaneous action potential generation was observed in 68 out of 75 cells tested; average spiking frequency being $2.13 \pm 0.32$ $\mathrm{Hz}$ (mean \pm s.e.m.). The firing frequency was highly variable between cells, ranging from 0.07 to $15.27 \mathrm{~Hz}$. This activity could be enhanced with $100 \mu \mathrm{M}$ picrotoxin (Figure 2D) or completely blocked by $1 \mu \mathrm{M}$ TTX (Figure 2D). In summary, spinal cord myelinating cell cultures are electrically active and activity can be manipulated bi-directionally using pharmacology.

Next, we examined functional responses of microglia/macrophages, which were evident as IBA1 (Figure 1B) or CD45 +ve cells, at all stages examined from DIV 7-28. To assess the phagocytic capability of microglia/macrophages for a relevant target, we added increasing concentrations of rhodamine-labelled myelin (subsequently referred to as 'myelin debris') on DIV 26 for $24 \mathrm{~h}$. The proportion of CD45 +ve cells incorporating myelin reached $\sim 66 \%$ of cells at 0.075 or $0.1 \mathrm{mg}$ myelin-protein $\mathrm{ml}^{-1}$. Internalized myelin appeared within lysosomal-associated membrane glycoprotein 1 +ve structures, indicating its incorporation into late endosomes/lysosomes (Figure 3A). To assess consequences of longer-term exposure to myelin debris, we incubated cultures for 1 or 7 days with myelin $\left(0.1 \mathrm{mg}\right.$ myelin-protein $\left.\mathrm{ml}^{-1}\right)$ from wild type or Plp1 transgenic mice (Plp1 tg line \#72; Readhead et al., 1994); the latter is a spontaneously demyelinating model of Pelizaeus Merzbacher disease (Anderson et al., 1999; Edgar et al., 2010) that like line \#66 (Ip et al., 2006) is characterized by low-level $\mathrm{T}$ cell infiltration into the CNS (JE unpublished observations). The proportion of CD45 +ve cells containing myelin debris did not change significantly over time, or with the 'genotype' of the myelin (Figure 3B). To compare receptor-dependent versus independent phagocytosis (Sierra et al., 2013), we quantified the proportion of cells incorporating myelin versus latex beads; however the proportions were similar (Figure 3B).

In the resting brain in vivo, microglial soma are rather stationery but their processes are highly motile (Davalos et al., 2005; Nimmerjahn et al., 2005). In response to focal injury, or 

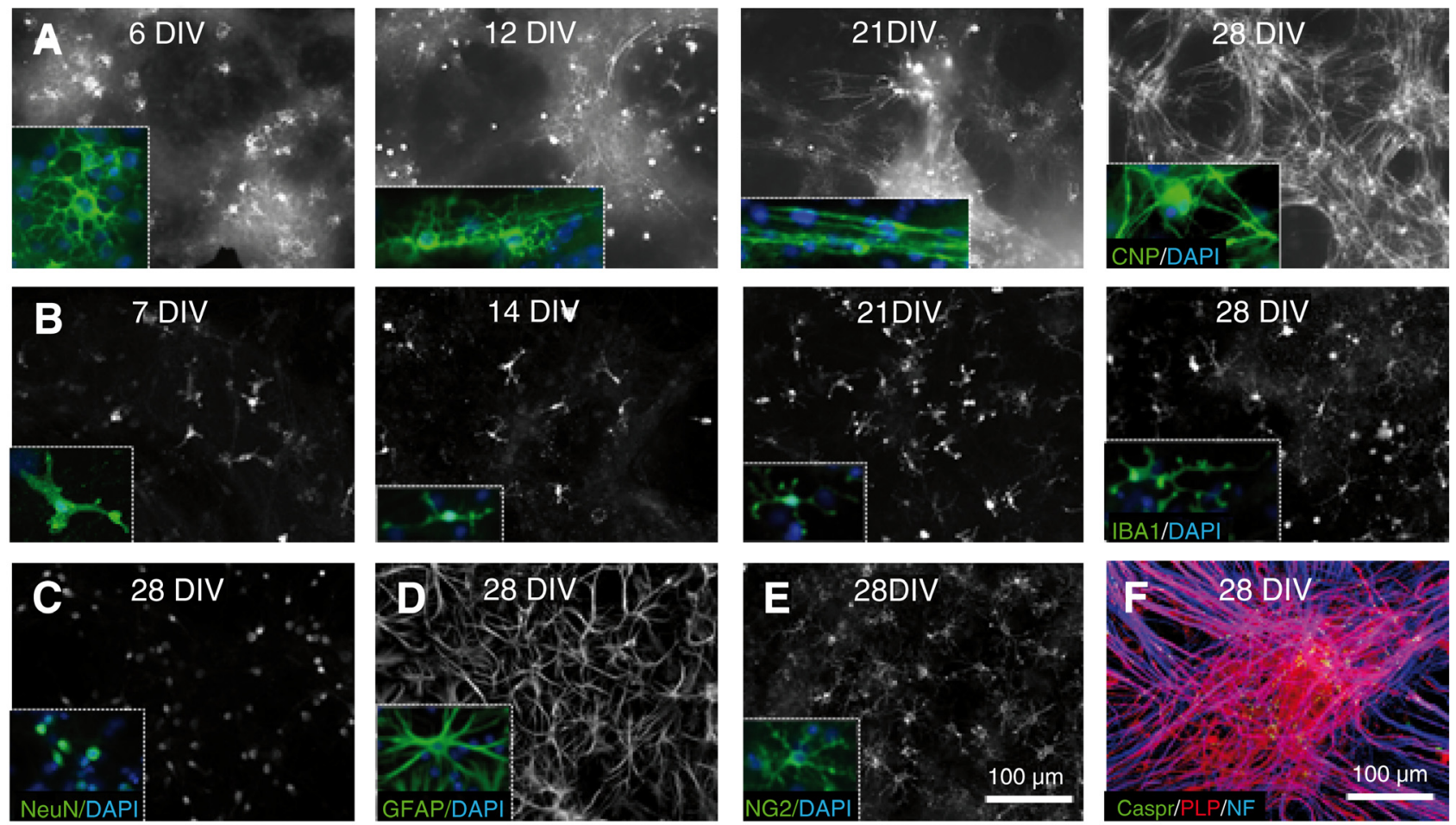

Figure 1. Embryonic day 13 mouse spinal cord cells differentiate over time into the major neural cell types of the nervous system. A. The morphology of CNP positive cells changes with time in culture. At 6 DIV, multiple cell process extend from the cell body and the cells have a 'lacy' appearance, as shown in the inset. By 12 DIV, a small number of myelin-like sheaths are present; often a single single sheath can be observed running in a line through one axis of an otherwise 'lacy-appearing' cell. In the inset, two such sheaths can be observed along 3 adjacent 'lacy-appearing' cells. By 21 DIV, many cells have extended multiple myelin-like sheaths and by 28 DIV few 'lacy-appearing' cells remain and a dense network of myelin sheaths are visible. When stained with antibodies to PLP/DM20, Caspr and phosphorylated neurofilament (NF), many axons are covered by consecutive sheaths with nodes of Ranvier straddled by Caspr positive paranodes (bottom right image). B. Iba1 +ve microglia are present at all stages examined. At 7DIV most microglia appear amoeboid but become ramified and extend multiple processes over time (insets). C. Antibody to NeuN labels neuronal nuclei and sometimes staining extends into the cytoplasm, but rarely enters the cell processes. D. GFAP positive astrocytes are found throughout the culture, (E) as are NG2 +ve OPCs. F. Combined staining with antibodies to PLP/DM20, Caspr and phosphorylated neurofilament (NF), reveals that many axons are covered by consecutive sheaths with nodes of Ranvier straddled by Caspr positive paranodes. Images A-F were contrast enhanced to ease viewing.

simulation of injury by local application of ATP, cell soma (Honda et al., 2001) or processes independent of the cell soma (Davalos et al., 2005), converge on the injury site. To assess the dynamic behavior of phagocytic microglia/macrophages in spinal cord-derived cultures, we used live imaging immediately following the addition of rhodamine-labeled myelin debris. Cells identified as microglia/macrophages on the basis of their incorporation of myelin debris, were motile with respect to both the soma and processes, appearing to 'gather' myelin debris for ingestion. Qualitatively, the vast majority of exogenous myelin was internalized within the $15 \mathrm{~h}$ imaging period (Figure 3C and Supplementary Video 1).

In vivo, microglia not only express receptors that mediate phagocytosis of cellular debris, but also initiate responses to pathogenassociated molecular patterns (PAMPs) such as endotoxins and viral nucleic acids, and damage-associated molecular patterns
(DAMPS) such as high mobility group box 1 (HMGB1) and ATP. To examine the secretory profile of spinal cord-derived cultures challenged with (i) lipopolysaccharide (LPS; from Gramnegative bacteria; $100 \mathrm{ng} \mathrm{ml}^{-1}$ final) or (ii) myelin debris $(0.05$ mg myelin-protein $\mathrm{ml}^{-1}$ final), we used a commercially available proteome array for the unbiased detection of 40 cytokines/ chemokines. In preparing myelin debris, we took care to minimize the risk of contamination by endotoxin, by using cellculture grade plastics and media wherever possible. As expected, LPS led to a significant increase in steady state levels of proinflammatory cytokines, TNF $\alpha$, IL1- $\alpha$, IL-6 (all p < 0.001), IL1 $\beta$ $(\mathrm{p}<0.01)$; anti-inflammatory cytokine IL1-ra $(\mathrm{p}<0.01)$; granulocyte colony stimulating factor (G-CSF; $p<0.001$ ); chemokines CCL1, CCL3, CCL4, CCL5, CCL12, CXCL1, CXCL2, CXCL10 (all p < 0.001), CXCL9 ( $<<0.05)$; soluble intracellular adhesion molecule 1 (sICAM1; p $<0.001$ ) and TIMP Metallopeptidase Inhibitor 1 (TIMP1; $<<0.001$ ), compared to PBS 
A

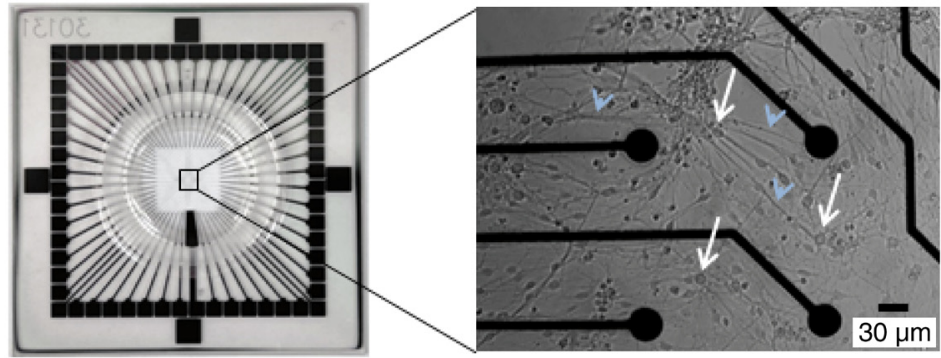

B

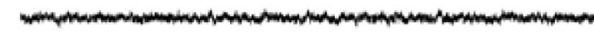

Day 20

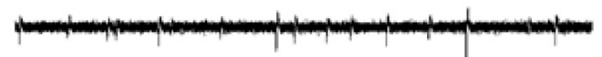

Day 21

$100 \mu \mathrm{V}$

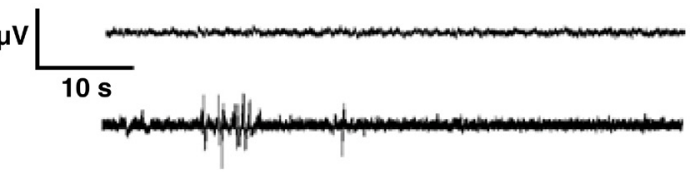

Day 23

Day 24

C

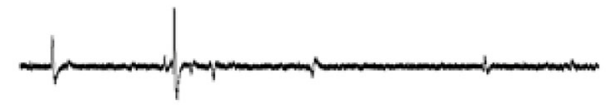

Control

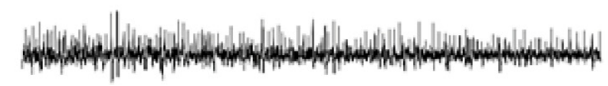

$100 \mu \mathrm{M}$ Picrotoxin

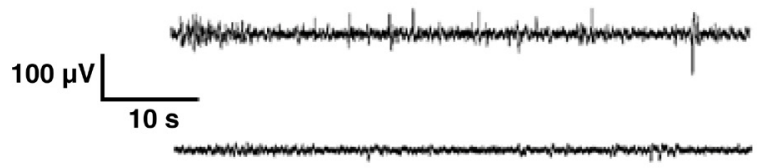

$5 \mu \mathrm{M}$ TTX

$5 \mu \mathrm{M}$ CNQX

D

Before picrotoxin

After picrotoxin

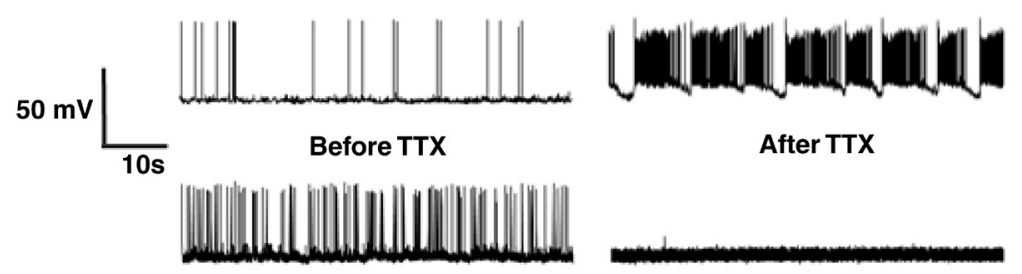

Figure 2. Myelinating cell cultures are spontaneously electrically active. A. Low power view of the whole MEA (left); all 59 recording electrodes and the ground electrode are concentrated in the center of the array. In the high-power image (right), four electrodes (black circles) can be observed in relation to the cell bodies (white arrows) and processes (including axons; blue arrowheads) of neurons and glia, on an MEA. To facilitate viewing, we selected a region in which cell density is lower than normal. Extracellular activity can be assessed from each of 59 recording electrodes. B. Extracellular recordings from a single electrode between 20 and 24 . DIV. Each trace represents the sum of the activity detected at that electrode, which is in direct contact with multiple neuronal and glial cell bodies and processes. 'Fast' spike-like activity is evident at DIV 21 and 'burst-like' activity develops by DIV 24. C. Additive pharmacology on a DIV 24 culture (sequential administration of drugs without washout) demonstrates in vivo-like neuronal network activity of spinal cord myelinating cultures. The recording shows that addition of picrotoxin, a GABAergic inhibitor, evokes a massive increase in 'fast' neuronal activity (second versus first trace). Subsequent addition of TTX (a Na+ channel blocker) inhibits much of the 'fast' spike-like (presumably axonal) activity. CNQX (a blocker of AMPA/kainate receptors) blocks excitatory synaptic activity. The remaining slow potential changes probably represent local spontaneous depolarizations (at neuronal and glial cell bodies). D. Examples of whole-cell current clamp recordings from single cells, presumably neurons, firing spontaneously at a resting potential of around $-50 \mathrm{mV}$. Top, trace before and 5 minutes after the addition of $1 \mu \mathrm{M}$ TTX (top). Bottom, trace from a second cell before and 5 minutes after the addition of $100 \mu \mathrm{M}$ picrotoxin. TTX consistently blocked activity ( $\mathrm{n}=6$ cells), as expected, whilst picrotoxin caused regular burst spiking in every cell tested ( $\mathrm{n}=18 \mathrm{cells}$ ), but the effect on overall spike rate was inconsistent, presumably reflecting the phenotype of the cell. 


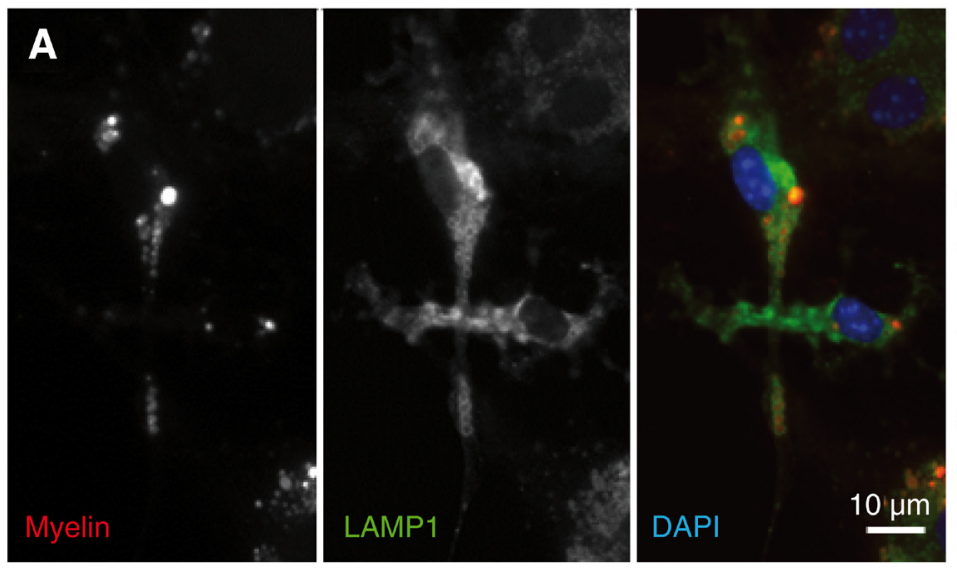

\section{B Myelin-containing CD45 +ve cells}
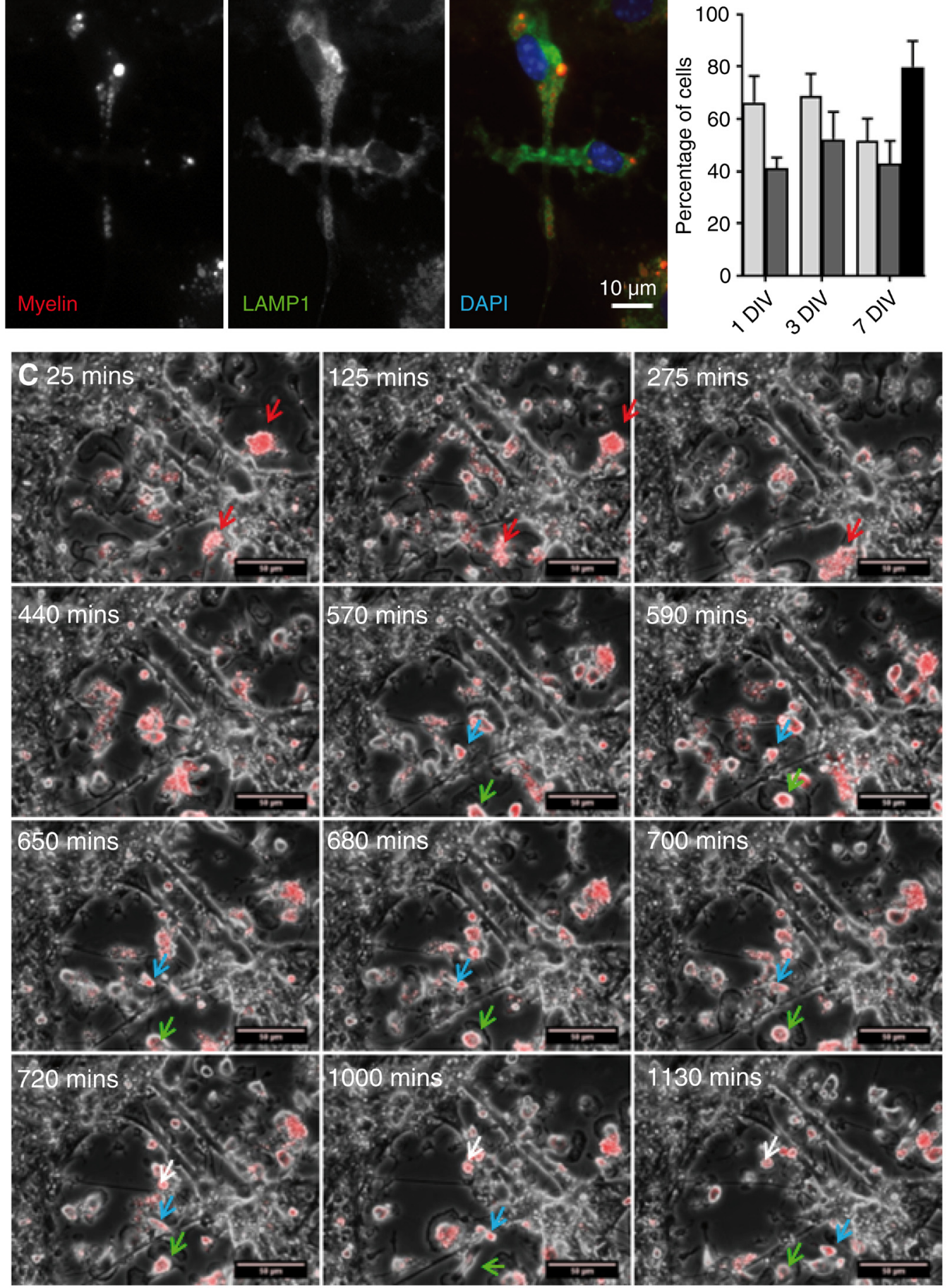

Figure 3. Motile microglia/macrophages take up myelin debris in vitro. (A) ID4B antibody staining of cultures treated with rhodaminelabelled myelin debris at 27 DIV shows myelin debris (red) within lysosomal associated membrane glycoprotein 1 (green) late endosomes/ lysosomes. All cells containing myelin were found to be CD45 +ve (not shown). (B) After incubation with saturating amounts of myelin debris (data obtained with 0.075 or $0.1 \mathrm{mg}$ myelin protein $\mathrm{ml}^{-1}$ were similar, so values from each were included providing two technical replicates) over three different time periods, the percentage of CD45 positive cells that contained 'wild type' (pale grey bars) or Plp1-tg (dark grey bars) myelin debris, which is taken up in a receptor-dependent manner, was between $40-70 \%$ ( $n=6$; 2 technical replicates for each of 3 independent experiments, per time point); not significantly different from the proportion that contained latex beads (black bar), which are taken up in a receptor-independent manner ( $n=3$ independent experiments). Bars represent mean $+/$ - s.e.m.. (C) Time lapse stills over 1130 minutes show myelin debris (red) at time of addition ( 25 mins $-275 \mathrm{mins}$ ) and then being phagocytosed by microglia/macrophages (440 mins - 1130 mins). Blue and green arrows highlight the locations of individual cells over time. 
( $n=3-4$ replicates from 2-3 independent cultures). A representative proteome array is shown in Figure 4A. In contrast, exposure of the cultures to myelin debris resulted in a much more restricted response, lacking upregulation of pro-inflammatory cytokines. However, chemokines CCL3 and CCL4 were significantly upregulated in cultures treated with either wild type or Plpl tg myelin, compared to vehicle-treated controls (PBS; Figure 4B and C), as were TIMP1 and M-CSF ( $<<0.001-0.05 ; \mathrm{n}=3$ independent cell cultures and 6 independent myelin preparations [3 WT and 3 Plpl tg]). Notably however, compared to wild type myelin debris, Plpl tg myelin debris was associated with significantly increased steady state levels of CXCL1, CXCL2, CXCL10 and CCL5 (Figure 4B and C), the last two of which are strongly linked to $\mathrm{T}$ cell infiltration into the CNS (reviewed Hughes \& Nibbs, 2018).

Together, these data demonstrate that innate immune cell properties, including phagocytosis of tissue debris and appropriate cytokine secretion profiles are reproduced in pure spinal cordderived myelinated cultures.

\section{Gene expression can be knocked-down in myelinating cell cultures using siRNA}

Having established these cultures recapitulate relevant in vivo functions, we next asked if they are amenable to manipulation using siRNA and thus capable of being used as a screen for gene silencing approaches. We selected 2', 3'-cyclic nucleotide 3'-phosphodiesterase (CNP), which is expressed early in the oligodendroglial lineage and eventually localized to the cell soma, processes and non-compact myelin (Trapp et al., 1988). We began by defining the temporal sequence of CNP expression using immunocytochemistry. We observed a small number of CNP + ve cell bodies as early as DIV 2, and by DIV 4, CNP was also observed in short cellular processes (data not provided). By DIV 6, multiple 'lacy-appearing' CNP +ve cells were visible (Figure 1A) and by DIV 12, occasional myelin-like profiles were present; often as a single myelin-like sheath extending from an otherwise 'lacy-appearing' cell (Figure 1A). Myelin-like profiles increased in number and extent with time, and the number of 'lacy-appearing' cells correspondingly diminished (Figure 1A).

To deplete Cnpl mRNA, cultures were incubated intermittently with siRNA from DIV 20, when CNP was already expressed (Figure 1A and Figure 5A), until DIV 31. CyB siRNA was used as a positive control. By western blot, steady-state levels of CNP or cyclophilin B were significantly reduced by their respective siRNAs, compared to non-targeting (NT) siRNA-treated controls (Figure 5A and B). In contrast, steady-state levels of proteolipid protein (PLP), myelin associated glycoprotein (MAG), actin, cyclophilin $\mathrm{B}$ or phosphorylated neurofilament heavy chain $(\mathrm{Ph} \mathrm{NF-H)}$, were not altered in $C y B$ or Cnpl siRNA-treated cultures compared to NT siRNA controls. With the exception of MAG, levels of all proteins were similar in NT siRNA-treated cultures compared to cultures treated only with Accell $\mathrm{DM}^{+}$ incubation medium (Figure 5A and B). Qualitatively, neurofilament medium chain (NF-M), acetylated tubulin, tyrosinated tubulin (Figure 5A) and mitochondrial-related proteins, OPA1, mitofusin and parkin (data not in the manuscript, but attached in raw data files, Exps N10, 12, 13, 23, 24 and 30, Dataset 1, (Bijland et al., 2019)) were also not obviously changed under any treatment conditions, suggesting siRNA is not toxic to these cell cultures, even after relatively long incubation times. Using immunocytochemistry with antibodies to CNP (in noncompact myelin), GFP (to stain CFP +ve neurones from the Thy1-CFP mouse embryos) and myelin basic protein (MBP; in compact myelin), CNP specifically appeared reduced in cell bodies and myelin sheaths in Cnpl siRNA-treated cultures compared to $\mathrm{DM}^{+}$only or $C y B$ siRNA-treated controls (Figure $5 \mathrm{C}$ and D).

In summary, this myelinating cell culture system is amenable to siRNA gene expression knockdown, in the absence of overt off-target effects.

\section{Myelinating cultures can be adapted to a semi-high throughput format}

We have previously used this culture system to identify factors that influence myelination, however to increase its utility in this respect we asked if it could be adapted it to a format that would allow semi-high throughput screening of multiple factors, simultaneously.

Empirically, we have observed that poly-L-lysine in boric acid buffer is a highly effective substrate for cell adhesion, therefore 96-well microplates were prepared accordingly, and E13 mouse spinal cord cells were plated at a density of 75,000, 85,000 or 100,000 cells/well. Using immunocytochemisty to label myelin sheaths (anti-MBP), axons (SMI31, anti-phosphorylated $\mathrm{NF}-\mathrm{H}$ ) and oligodendroglia (anti-Olig 2), we found that a starting density of 100,000 cells/well led to a reproducible generation of myelinated axons after 24 DIV (data not shown). Qualitatively, plating densities of $<100,000$, led to lower levels of neuritic outgrowth and myelination.

As most small molecule libraries are diluted in DMSO, we checked if DMSO adversely affected the cultures. Growing the cells in the presence of $1 \%$ DMSO had no significant effect on axon density or myelination (mean difference $2.4 \%$ for axon density, mean difference $0.4 \%$ for myelin, (see raw data files pertaining to Figure 6 and Figure 7, Dataset 1, (Bijland et al., 2019)).

Next, we established a protocol for automated image capture using the IN Cell Analyzer 2000 High Content Screening microscope (GE Healthcare), and an automated image quantification method using CellProfiler (Carpenter et al., 2006). Our analysis protocol quantified nuclear number, phosphorylated neurofilament (axonal) area and PLLS (power log-log slope, as an indicator of amount of blur in the image) and excluded images with nuclei numbers $<1500$, axon area $<40 \%$ or PLLS $>-2.0$. For each image that passed quality control, the area occupied by myelin-like sheaths (stained with anti-MBP) and the area occupied by phosphorylated neurofilament (stained with antibody SMI31) were quantified, and MBP area expressed as a proportion of neurofilament area.

To test if our automated image capture and quantification protocols were sufficiently robust to detect changes in myelination, we treated myelinating cultures from day 19 with FGF9, a known 
A

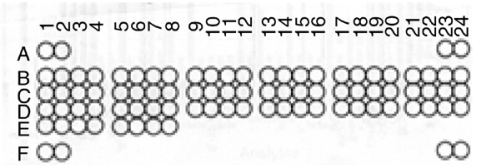

\section{DIV incubation}

B
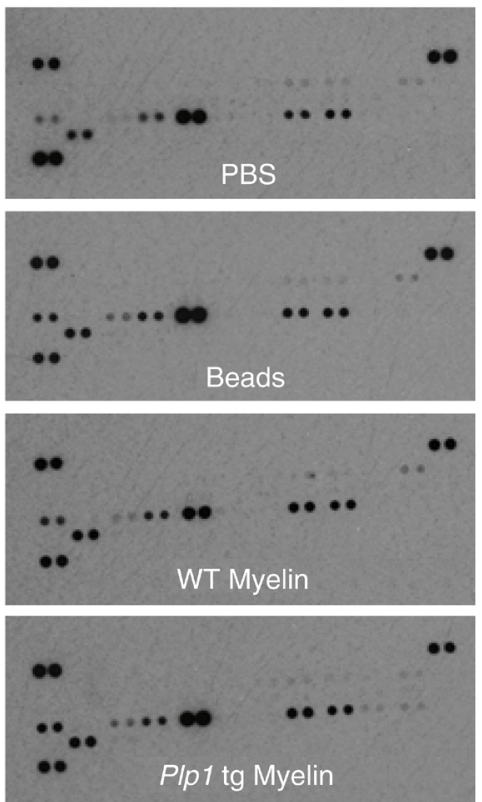

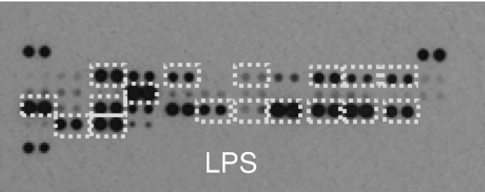

7 DIV incubation
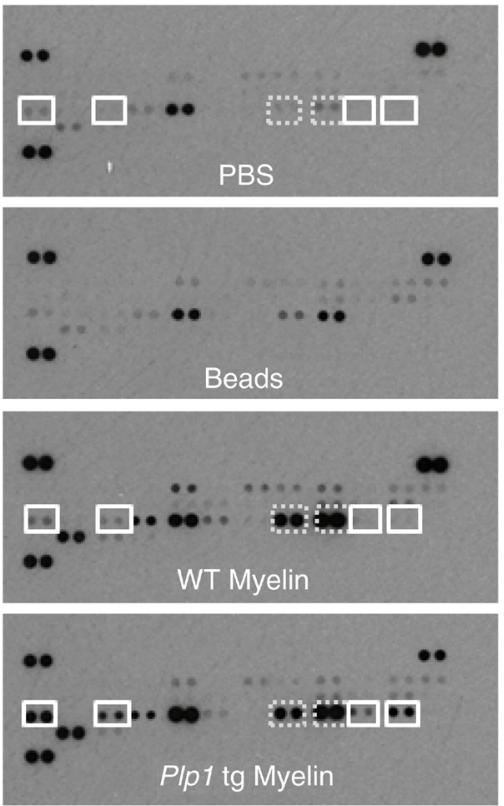

C Upregulated chemokines

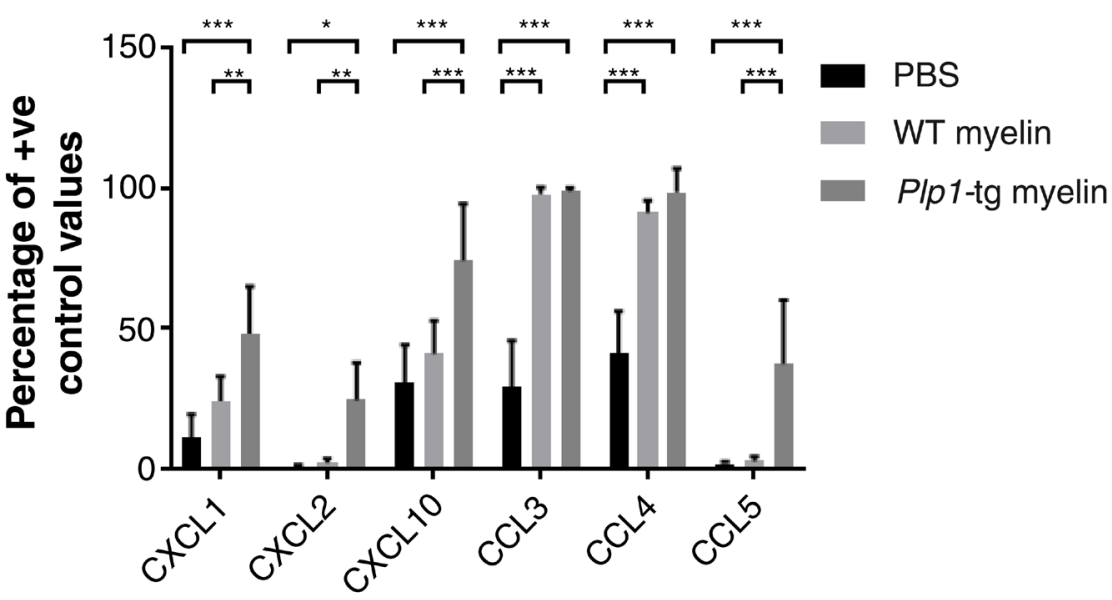

Figure 4. Spinal cord cultures mount appropriate responses to diverse stimuli. A. Map of proteome arrays shows six positive control $(A 1,2 ; A 23,24 ; F 1,2)$ and two negative control $(F 23,24)$ spots, alongside 40 paired cytokine-specific spots $(B 1,2-E 7,8)$. The array on the right was incubated with medium from cultures treated with LPS. A number of cytokines and chemokines (highlighted with white boxes), including pro-inflammatory cytokines, were upregulated in LPS-treated cultures compared to PBS-treated controls. Quantification is provided in the text. B. Proteome arrays incubated with medium from cultures treated with a myelin-enriched tissue fraction from wild type or a spontaneously demyelinating model of Pelizaeus Merzbacher disease (P/p 1 tg myelin) for 1 or 7 days. After 7 days, two chemokines were upregulated in cultures treated with wild type or Plp1 tg myelin compared to PBS-treated cultures (highlighted with boxes with broken lines). An additional four chemokines were upregulated specifically in Plp $1 \mathrm{tg}$ myelin-treated cultures compared to wild type myelin-treated cultures (highlighted with boxes with solid lines). C. Graph of chemokines upregulated in cultures treated with myelin-enriched tissue preparations for 7 days. Bars represent mean +/- s.e.m. $n=3$ independent cultures to which 6 independent myelin preparations were added (1 preparation per independent experiment from wild type mice and 1 preparation per independent experiment from Plp 1 transgenic mice). Each cell culture (considered $\mathrm{n}=1$ independent biological repeat) comprises up to $24 \times 35 \mathrm{~mm}$ dishes each containing 3 coverslips coated with cells. Eight $35 \mathrm{~mm}$ dishes are contained within one $25 \mathrm{~mm}$ diameter dish. Wild type or P/p 1 transgenic myelin were added to two $35 \mathrm{~mm}$ dishes, from within one larger $25 \mathrm{~mm}$ diameter dish. There was no systematic selection process for deciding which dishes would receive wild type versus Plp1 transgenic myelin, as all dishes were identical. Raw data files attached. ${ }^{*} p<0.05,{ }^{* *} p<0.01,{ }^{* * *} p<0.001$. 
A

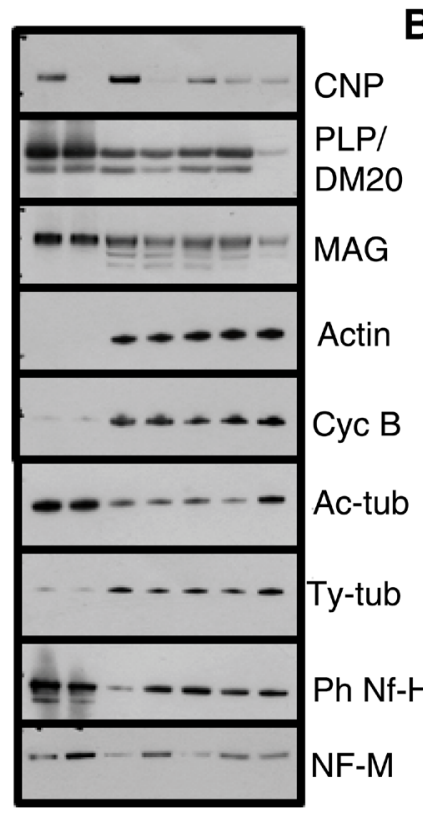

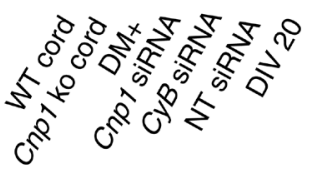
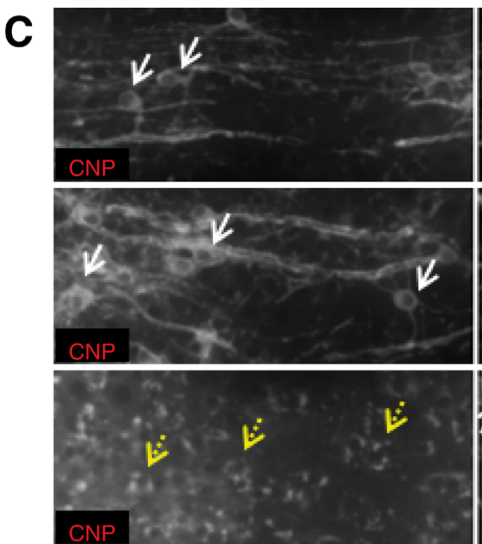

D

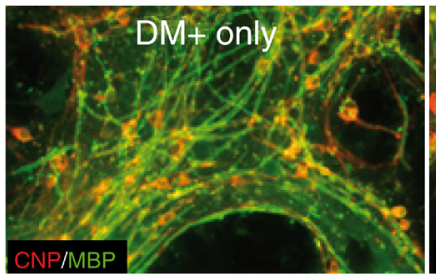

B
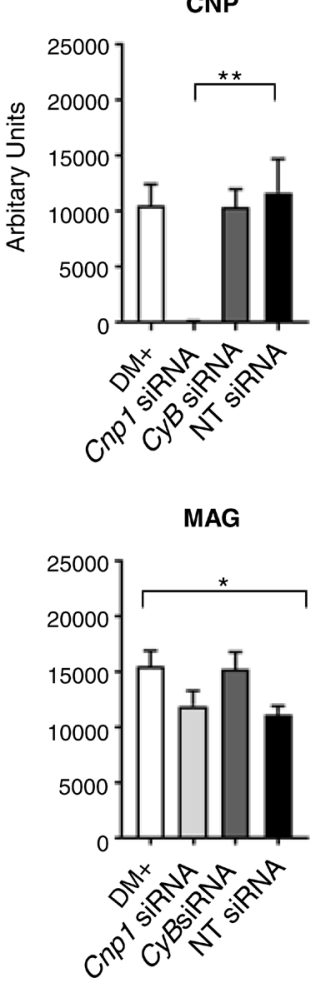

Cyclophilin B

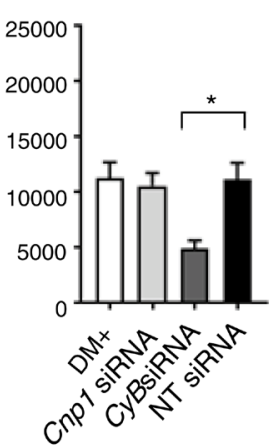

Actin

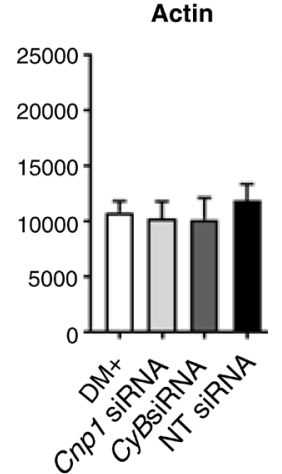

PLP

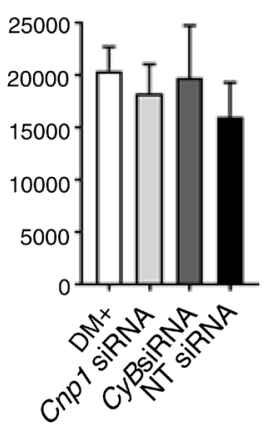

Ph Nf-H

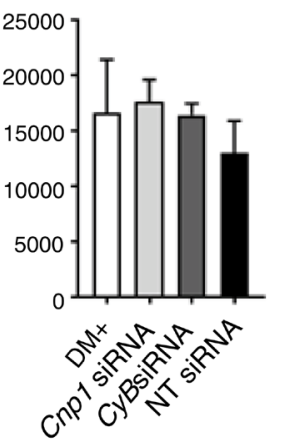

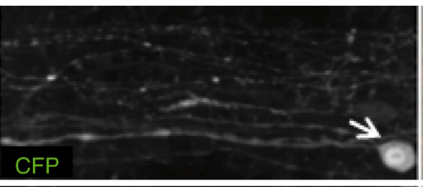
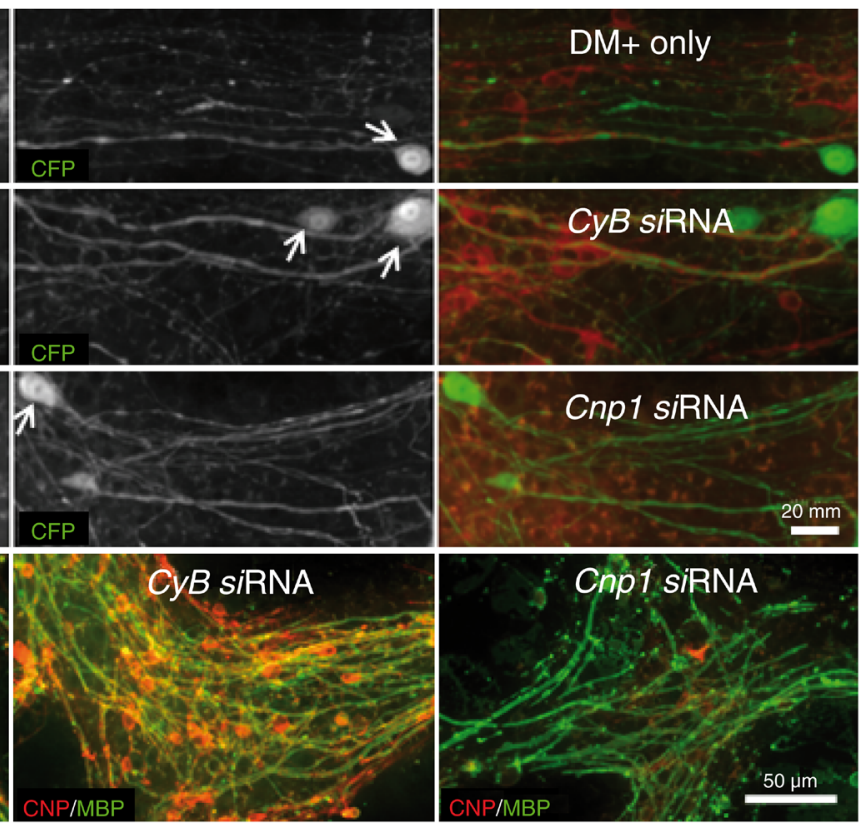

Figure 5. Spinal cord cultures are amenable to gene knockdown using siRNA. A. Western blots of (from $L$ to $R$ ) spinal cord lysates from wild type and Cnp1 knockout (ko) mice and cell lysates from DIV 30 spinal cord cultures following treatment with supplemented incubation medium only (DM+), Cnp1 siRNA, CyB siRNA or non-targeting (NT) siRNA. Lysates from time 0 (DIV 20) cultures, were run alongside. B. Quantification myelin proteins, housekeeping proteins and axonal proteins in siRNA treated cultures. Bars represent mean $+/-$ s.e.m. Values were obtained from $n=4-7$ independent cultures. Seven independent experiments were undertaken but some proteins were only examined in 4, 5 or 6 of these as shown in the attached raw data files. All 7 experiments were probed for CNP and 6 of 7 were probed for cyclophilin B, against which the siRNA was designed. * $p<0.05$, ${ }^{* *} p<0.01$. C. Micrographs of cultures prepared from Thy $1-C F P$ mouse embryos, treated with DM+, CyB siRNA or Cnp1 siRNA, and stained with anti-GFP (binds CFP which is expressed in a subset of neurons) and anti CNP. White arrows point to CNP +ve oligodendrocyte cell bodies or CFP + ve neuronal cell bodies. The punctate 'staining' indicated with broken yellow arrows represents autofluorescent lipofuscin granules, which are prevalent in these cultures. CNP is markedly reduced in Cnp1 siRNA-treated cultures. D. Micrographs of cultures treated with DM+, CyB siRNA or Cnp1 siRNA, and stained with anti-MBP (MBP is located in compact myelin) and anti-CNP (CNP is located in non-compact myelin). CNP is markedly reduced in Cnp1 siRNA-treated cultures, but MBP appears unchanged. 
A

Control

Activin A
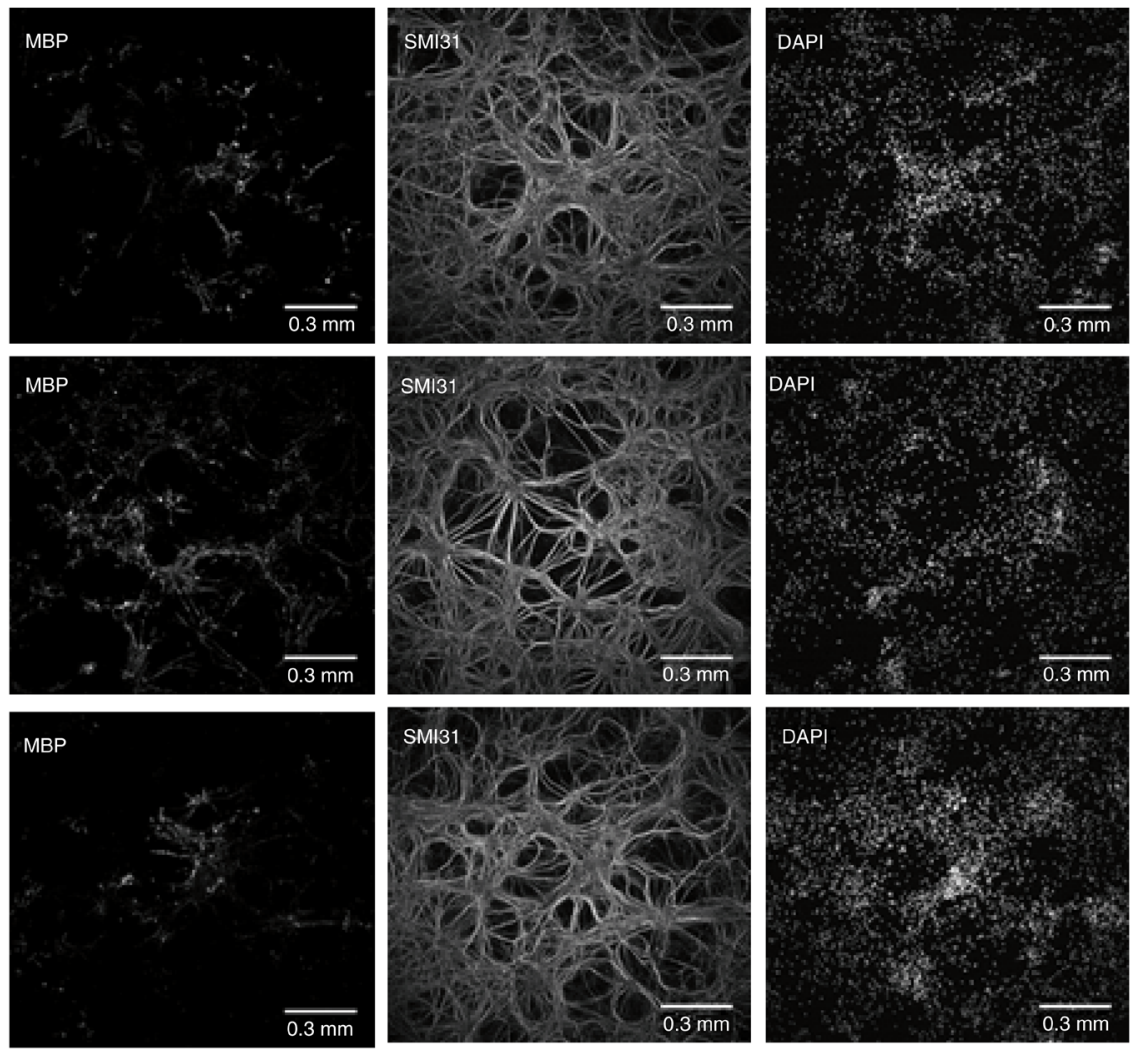

B
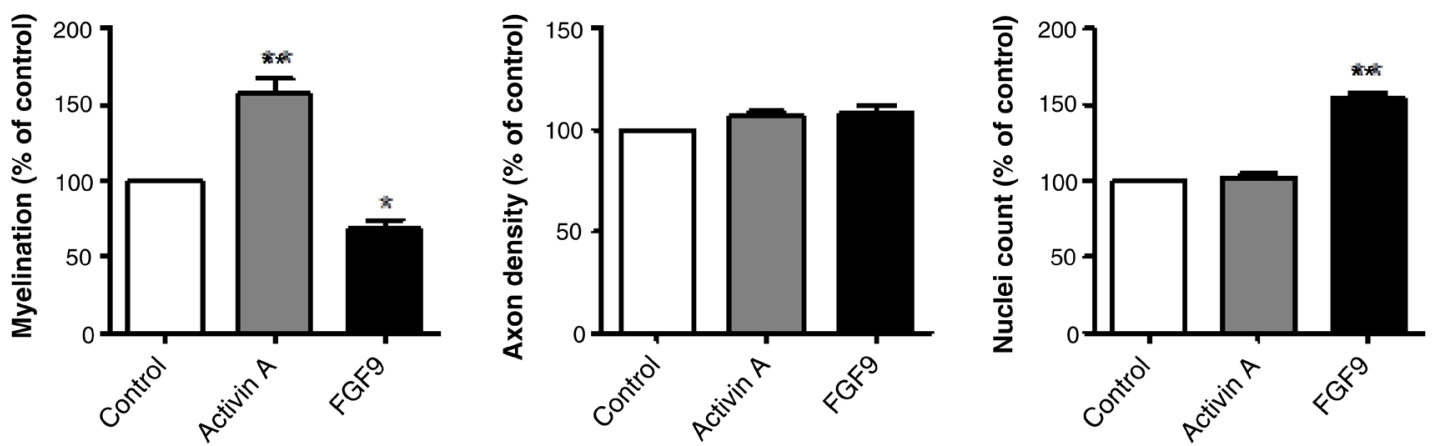

Figure 6. Spinal cord cultures grown in 96-well microplates are amenable to modulators of myelination. A. Representative immunofluorescence images of 96-well microplate myelinating cultures (28 DIV) stained for MBP, phosphorylated neurofilament (SMI31) and nuclei (DAPI). Cells were untreated or treated with Activin-A or FGF9 as described. B. Percentage change in myelination, axon density and nuclei count after treatment with Activin-A or FGF9. Bars represent average values from 5 independent cultures, each with 5 wells of technical replicates (wells), +/- s.e.m.. Raw data attached. Cells were allocated to different treatments as described in Materials and Methods. ${ }^{*} p<0.05,{ }^{* *} p<0.001$

mitogen and inhibitor of myelination (Lindner et al., 2015), or from day 15 with activin A, a known enhancer of myelination (Goebbels et al., 2017; Miron et al., 2013) until DIV 28. FGF9 induced a significant $(-31.7 \%, \mathrm{p}<0.05)$ decrease in myelination while activin A (100 ng ml-1) produced a significant $(+56.5 \%$, $\mathrm{p}<0.001)$ increase in myelination, relative to vehicle-treated cultures (Figure 6). Furthermore, FGF9 (100 ng ml-1) led to a significant $(+53,8 \%, \mathrm{p}<0.001)$ increase in nuclear density (average of 5 independent experiments; each with 5 technical repeats), as expected for a pro-proliferative factor (Lindner et al., 2015). To test the sensitivity of our assay, we treated cultures with $1,5,10,50$ or $100 \mathrm{ng} \mathrm{ml}^{-1}$ activin $\mathrm{A}$ and found that increasing concentrations (1-100 ng/ml) of activin A led to a dose-dependent increase in the degree of myelination (Figure 7; average of 2 independent experiments; each with 5 technical repeats).

Thus, the methods are robust and sufficiently sensitive to detect small changes in myelination and cell densities. 


\section{$\mathrm{ng} / \mathrm{ml}$ Activin A}
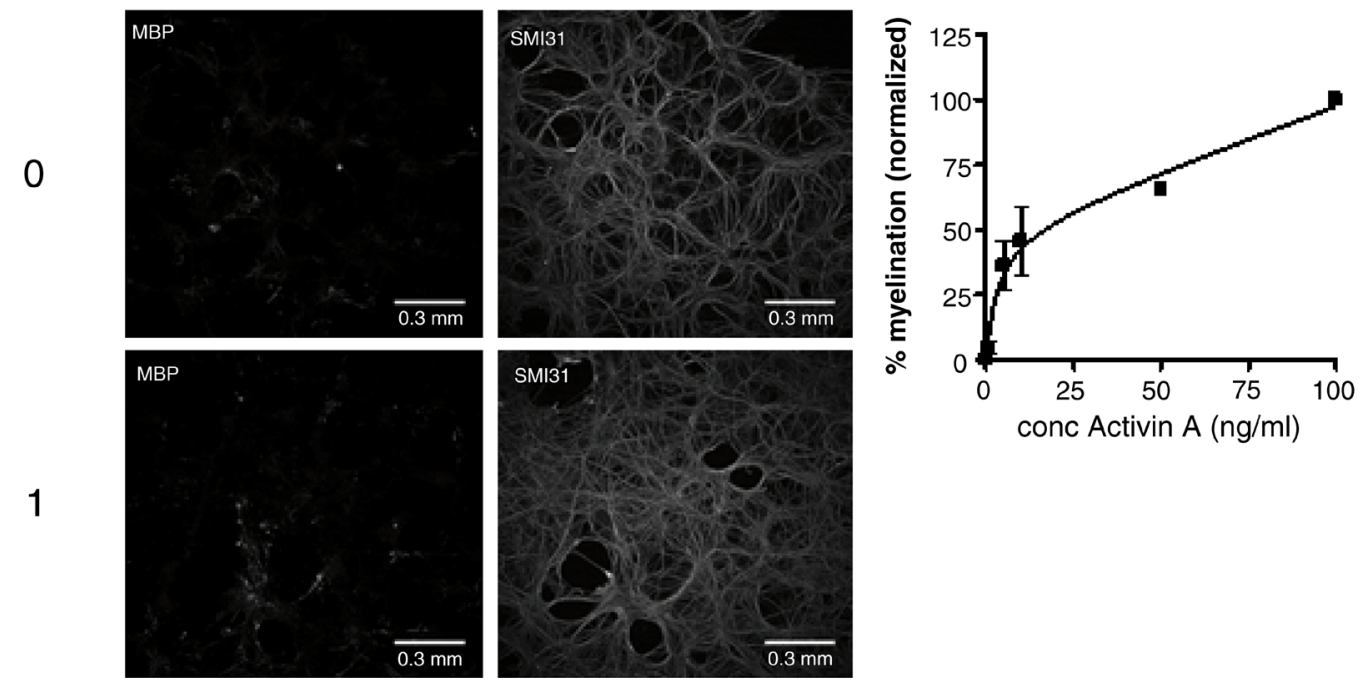

1

5
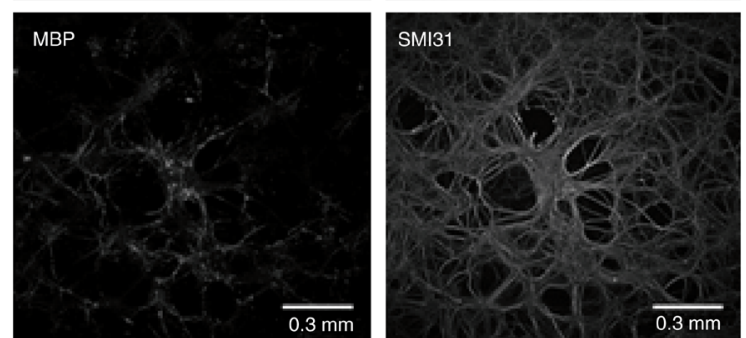

10
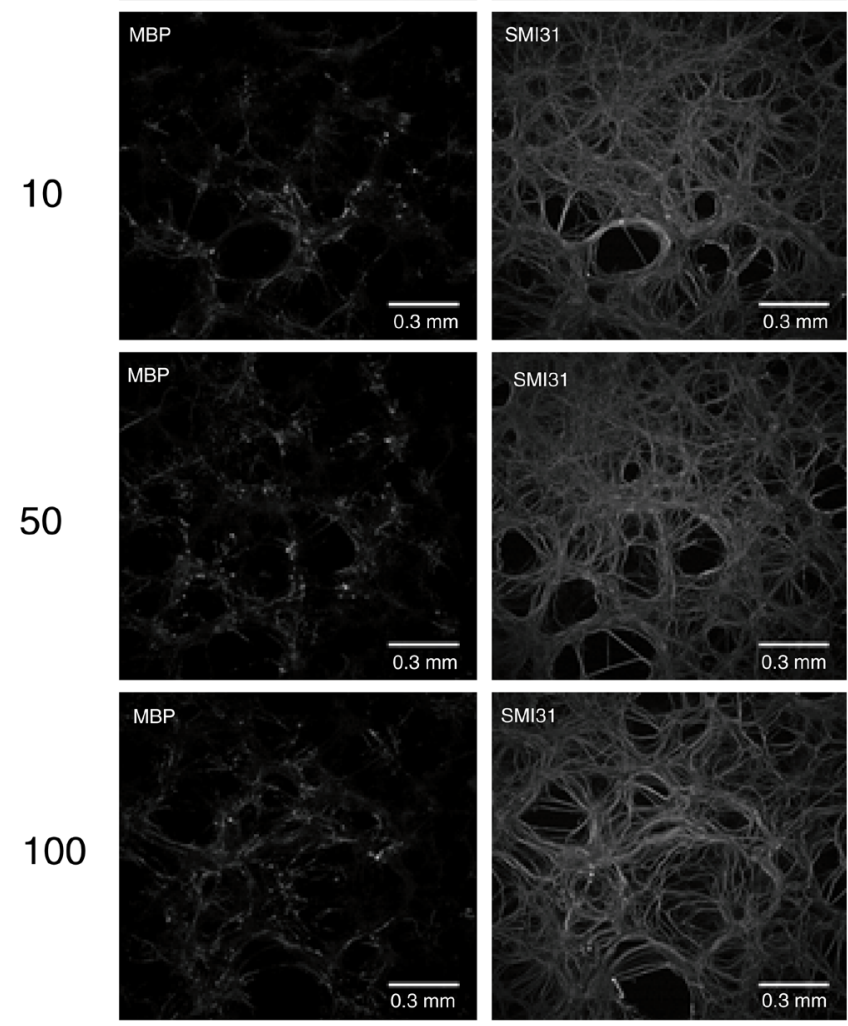

Figure 7. Microplate assays are sensitive to small changes in myelination. Spnal cord cultures were treated with increasing doses of Activin-A. A. Representative immunofluorescence images of 96-well microplate myelinating cultures (28 DIV) stained for MBP and phosphorylated neurofilament (SMI31). B. Dose-response curve for myelination in response to Activin-A treatment. Average values from 2 independent cultures, 5 technical repeats per culture, +/- s.e.m. 
As libraries of small molecules are costly, we proceeded to test whether myelinating cultures could be grown in 384-well microplates, which would allow markedly smaller amounts of compounds to be used in each assay. We plated spinal cord cells at densities of $30,000,40,000$ or 50,000 cells/well and stained the cultures with antibodies to phosphorylated neurofilament and MBP. Qualitatively, we found that the optimal plating density was 50,000 cells/well but the cultures tended to be less reproducible in this format.

\section{Dataset 1. An in vitro model for studying CNS white matter:} functional properties and experimental approaches

https://dx.doi.org/10.5256/f1000research.16802.d233269

\section{Discussion}

Here we demonstrated that a murine, pure spinal cord-derived cell culture system (Thomson et al., 2006; Thomson et al., 2008) recapitulates several in vivo cellular functions, namely, spontaneous spinal-like electrical activity; phagocytosis of tissue debris; and appropriate secretory responses to diverse stimuli. Further, the system, which is straightforward to establish, can be used to assay gene-silencing approaches; adapted to a 96-well format for semi-high throughput assays of multiple factors simultaneously; or for growth on MEAs to monitor electrical properties. These advances increase the utility of this system for studies to address white matter development, function and pathology, providing the research community with a robust experimental tool that reduces costs and minimises the use of experimental animals. In particular, the multi-well format allows large numbers of factors to be assayed in parallel, whilst simultaneously reducing the numbers of mice required to provide tissue.

Whilst this in vitro model of CNS white matter is not intended to replace all animal work, it can inform, or augment such experiments. For example, we previously identified pro-myelinating factors from a list of candidates generated from transcriptomic analyses of laser-captured CNS tissue from Pten conditional knockout and control mice, using 11 independent cell cultures (Supplementary Figure 8 h; Goebbels et al., 2017) from 11 pregnant dams. A similar in vivo experiment would first require invasive surgery to administer a demyelinating agent into the CNS, followed by subsequent administration of the pro-myelinating compounds by the same route. Given that 8 compounds were analysed (Goebbels et al., 2017), a similar in vivo study would require the same 8 compounds to be administered to a least 11 mice per treatment group, assuming variation similar to that observed in cell culture; requiring at least 88 experimental animals. In this instance, our in vitro model affords an $87.5 \%$ reduction in the number of animals required compared to a similar in vivo experiment.

\section{Microelectrode arrays increase the utility of spinal cord} cultures

In CNS white matter, a supra-threshold axon caliber is necessary for initiation of myelination (Mayoral et al., 2018) and, when experimentally induced, is associated with de novo myelination of axons that ordinarily, are not myelinated (Goebbels et al., 2017). Myelin formation is further modulated by neuronal signals, including activity-dependent signals (Gibson et al., 2014; Hines et al., 2015; Mensch et al., 2015; Mitew et al., 2018). In neurons themselves, action potential firing patterns modulate the abundance of neuronal mRNAs across many functional gene categories affecting, for example, neurite outgrowth, synaptic connections and neural network formation (Lee et al., 2017), whilst conversely, protein levels can modulate neuronal activity (Lopez de Armentia et al., 2007). Thus, the circular relationship between fast electrical responses and longer-term changes in gene expression is important for nervous system development and plasticity (Lee et al., 2017). Here we demonstrated that spinal cord-derived myelinating cultures are spontaneously electrically active, and likely subject to similar bidirectional regulation of gene expression in neurons and in oligodendrocytes.

Neural electrical activity readouts provide information on factors such as cell phenotype, metabolic status and health. As few laboratories are equipped with the necessary equipment and expertise to perform intracellular recordings, we reasoned that commercial MEAs might provide an accessible method for assaying global extracellular electrical responses. Using MEAs we identified fast spike-like, low amplitude extracellular activity that increased in frequency in the presence of the GABA receptor antagonist, picrotoxin, suggesting that inhibitory neurons suppress this spontaneous activity. Conversely, spike-like activity was reduced by the voltage-gated sodium channel blocker, TTX, indicating it represents axonal action potentials. The AMPA receptor antagonist, CNQX, blocked some of the TTX-resistant activity, suggesting it represents changes at dendrites brought about by the synaptic release of glutamate. This is compatible with ultrastructural observations in these cultures (Figures $6 \mathrm{~F}$ and G; Thomson et al., 2008). To validate these MEA data, we used single cell current clamp recording which confirmed that high frequency action potential activity was present and could be enhanced by picrotoxin, or blocked by TTX (Figure 2) or CNQX (raw data provided separately, Dataset 1, (Bijland et al., 2019)); the last demonstrating it is glutamate-dependent. However, it is important to bear in mind that the extracellular activity recorded on the MEAs represents the sum of all neuronal and glial electrical responses at the recording electrode.

In terms of ease of use, spinal cord cells adhered well to MEAs and appeared, under phase contrast microscopy, indistinguishable from cells grown on glass. MEAs do not require the same specialist expertise or equipment needed for intracellular recordings and have the advantage that electrical activity can be assessed sequentially over days or even weeks. Further, they provide an overview of activity that cannot be achieved easily using intracellular recordings. Consequently, MEAs increase the utility of this multi-cell type culture for studies such as ion channel screening, drug testing and safety pharmacology.

\section{Spinal cord-derived cultures mount appropriate responses} to diverse stimuli

In response to infectious, autoimmune or physical insults, microglia mount neuroinflammatory responses to combat pathogens and enhance repair and restoration of function (reviewed in Song \& Colonna, 2018b; Song \& Colonna, 2018a). However, this response must be finely balanced as excessive or chronic neuroinflammation can, in some circumstances, contribute to 
disease pathogenesis (Song \& Colonna, 2018b; Song \& Colonna, 2018a; Song et al., 2017). Pattern recognition receptors (PRRs) on microglia play a major role in the initiation of these responses. Originally discovered for their role in recognizing pathogenderived molecular signatures, PRRs also respond to damage associated molecular patterns (DAMPs) released by dying or damaged cells, such as ATP, high mobility group box 1 protein (HMGB1), beta amyloid and $\alpha$-synuclein (Kigerl et al., 2014). Chronic generation of DAMPs within the CNS can therefore run the risk of causing secondary, collateral tissue damage by sustaining long-term activation of pro-inflammatory responses (reviewed in Song et al., 2017).

To determine if spinal cord-derived cultures respond appropriately to a classical PAMP, we challenged them with bacterial lipopolysaccharide (LPS) and compared their response to that induced by myelin debris; sterile clearance of which is essential to promote lesion repair in demyelinating diseases such as MS and experimental models (Kotter et al., 2005; Napoli \& Neumann, 2009; Neumann et al., 2009) in a CX CR1-and TREM2-dependent manner (Cantoni et al., 2015; Lampron et al., 2015; Poliani et al., 2015). LPS is a well-characterized PAMP that activates toll-like receptor 4 (TLR4) to up-regulate expression of pro-inflammatory cytokines and chemokines by a wide variety of immune cells (Chow et al., 1999).

As the resident immunocompetent population of the CNS, microglia express multiple toll-like receptors, including TLR4 (Bsibsi et al., 2002; Zhang et al., 2014) and initiate inflammation in response to PAMPs by secreting pro-inflammatory factors. These include cytokines such as tumor necrosis factor (TNF)- $\alpha$, interleukin (IL)-1 $\beta$, and IL-6 and free radicals such as nitric oxide (NO) (Hanisch \& Kettenmann, 2007; Hines et al., 2013; Tambuyzer et al., 2009). This was replicated in spinal cord myelinated cultures, in which LPS increased secretion of proinflammatory cytokines (IL-1 $\alpha$, Il1 $\beta$, IL-6 and TNF $\alpha$ ), as well as CCL and CXCL chemokines, mimicking the CNS response induced by viruses, bacteria or parasites (Forrester et al., 2018; Lobo-Silva et al., 2016). In striking contrast, clearance of 'wild type' myelin debris in these cultures did not induce an overt proinflammatory response, but selectively increased secretion of CCL and CXCL chemokines. This is in agreement with the homeostatic roles of microglia (and astrocytes) associated with clearance of myelin and other cellular debris injury (Perry et al., 1985).

Conspicuously however, challenging cultures with Plpl-tg myelin resulted in additional up regulation of CCL5 and CXCL10. Whilst chemokines facilitate context-dependent migration of all immune cells, CCL5 and CXCL10 and their receptors are particularly relevant with respect to $\mathrm{T}$ cell recruitment into the brain (Hughes \& Nibbs, 2018). These observations are especially interesting in light of the fact that increased numbers of $\mathrm{T}$ lymphocytes are present in the CNS of spontaneously demyelinating Plp1 tg mouse models of Pelizaeus Merzbacher disease (PMD), caused by gene duplication (JE, unpublished observations and Ip et al., 2006). CXCL10 expression is induced by type I interferons to recruit $\mathrm{T}$ lymphocytes into the CNS to protect against neurotropic viral infections (Liu et al., 2000) and it and its receptor, CXCR3, are necessary for induction of experimental cerebral malaria (ECM); probably due to the critical role CXCL10 plays in $\mathrm{T}$ cell-endothelial cell adhesion, and injury of the brain endothelium (Sorensen et al., 2018). Further, the increased susceptibility to encephalitic symptoms after infection with West Nile virus, of individuals harbouring mutated CCR5, which encode the receptor for CCL5, is thought to be due to failure of trafficking of $\mathrm{T}$ cells into the brain (Glass et al., 2005) and reviewed in (Hughes \& Nibbs, 2018). The molecular basis for the difference in chemokine induction between the two myelin 'genotypes' is not known; although our working hypothesis is that myelin isolated from Plpl tg mice is subtly altered allowing it to cross-link or activate additional receptors at the microglial surface (Lennartz \& Drake, 2018).

The importance of replicating the multi-cell type environment of the CNS when studying microglial functions such as these is highlighted by the fact that microglial phenotypes are modulated by neighboring cells and vice versa. For example, LPS-induced secretion of IL-1 $\beta$ and TNF by microglia can result in potent induction of pro-inflammatory gene expression by astrocytes in vitro (reviewed in Saijo \& Glass, 2011), whilst signaling induced by microglial CD172, CD200R and CD45 interacting with CD47, CD200 and CD22, respectively at the neuronal cell surface, inhibits microglial activation (reviewed in Saijo \& Glass, 2011).

\section{Spinal cord cultures can be used to test gene-silencing strategies}

Neurodegenerative diseases, including those that predominantly affect white matter, such as the leukodystrophies and amyotrophic lateral sclerosis (ALS) remain largely untreatable or relatively refractory to currently available therapies. In both cases, a dominant gain-of-function effect of the protein products of mutated genes contribute to pathogenesis in some forms of these diseases, for example in familial amyotrophic lateral sclerosis (fALS) due to mutation in SOD1 gene and in Pelizaeus Merzbacher disease (PMD) due to point mutation or duplication of the PLP1 gene (reviewed in van Zundert \& Brown Jr., 2017; Nave \& Griffiths, 2004). Thus, gene silencing using siRNA or antisense oligonucleotides represents a rational approach to treatment that is potentially devoid of some of the problems caused by the broad modes of actions of small molecule-based drugs (Zheng et al., 2018). A number of issues related to the systemic administration of siRNA or antisense oligonucleotides for CNS disorders remain to be overcome, such as delivery in the blood circulation, passage across the blood-brain barrier, and targeting to the appropriate cell type (Zheng et al., 2018). Nonetheless, it is important to have relevant in vitro models to carry out preliminary tests of the efficiency of gene knockdown and to screen for off-target effects before proceeding to in vivo studies. This is particularly important for genes expressed in postmyelination oligodendrocytes; cells whose phenotype is altered when they wrap axons.

\section{Spinal cord cultures are amenable to use in semi-high throughput assays}

Unlike PMD and fALS, which are genetically determined, MS is an acquired inflammatory demyelinating disease, affecting more 
than 2 million people worldwide (World Health Organization, 2008). MS involves a neurodegenerative process driven in part by the failure of MS lesions to remyelinate (Franklin \& FfrenchConstant, 2008; Franklin et al., 2012; Trapp \& Nave, 2008). Consequently, a potential therapeutic approach is to stimulate remyelination; an effect that enhances functional recovery (Duncan et al., 2009) and is predicted to reduce ongoing axonal loss (Irvine \& Blakemore, 2008; Mei et al., 2016). Spontaneous remyelination in MS is incomplete, leaving many axons chronically devoid of myelin (Patani et al., 2007). This is thought to render them vulnerable to inflammatory insult and devoid of oligodendroglial-mediated support (Franklin et al., 2012; Nave \& Trapp, 2008; Trapp \& Nave, 2008). In the adult brain, new myelin sheaths are formed by OPCs (Crawford et al., 2016; Keirstead \& Blakemore, 1997; Zawadzka et al., 2010), which are often abundant in MS lesions but fail to myelinate the naked axons (Chang et al., 2000; Chang et al., 2002; Scolding et al., 1998). Recent studies are beginning to identify drugs, small molecules and pathways that can be modulated to overcome remyelination failure. These include Wnt/ $\beta$-catenin (Fancy et al., 2009), retinoid $\mathrm{X}$ receptor gamma $(\mathrm{RXR} \gamma)$ signalling (Huang et al., 2011), muscarinic receptor antagonists such as benztropine and clemastine (Deshmukh et al., 2013; Mei et al., 2014) activin A (Goebbels et al., 2017; Miron et al., 2013) and drugs including miconazole and clobetasol (Najm et al., 2015). However, there is still a need for a cost-effective screening strategy to identify molecules with therapeutic potential for the treatment of MS and other multifactorial neurodegenerative disorders.

A valuable pre-in vivo screen of candidate therapeutics should fulfil certain criteria. First, it should contain all major cell types of the CNS, to resolve off-target effects of the test agent. Second, it should be simple to establish, reproducible, sensitive and unbiased. Third, it should be unaffected by carriers such as DMSO. Fourth, it should be capable of screening a substantial number of agents while using the minimum number of experimental animals. Finally, it will provide added-value if it can be generated from mouse models of disease and/or transgenic reporter mice for live imaging or expression analysis. Here we demonstrated murine spinal cord-derived cultures meet these criteria for semi-high throughput screens and recapitulate relevant functional properties of CNS white matter. Given the ease with which they can be established, this system provides laboratories with a simple, functional and relatively inexpensive method to explore normal and pathological processes relevant to white matter in general, and spinal cord in particular.

\section{Data availability}

Underlying data is available from F1000Research

F1000Research: Dataset 1. An in vitro model for studying CNS white matter: functional properties and experimental approaches, https://doi.org/10.5256/f1000research.16802.d233269 (Bijland et al., 2019)

Data is available as a zip file contain the corresponding data for the following figures:
Figure 1- Raw microscope image files

Figure 2B, C and D and for CNQX treated cell (not shown in Figure 2) - electrophysiology recording values.

Figure 3B - images and quantification of densities of CD45 +ve cells and the proportions that contain wild type, Plpl transgenic myelin or latex beads.

Figure 4C - scans of X-ray films of proteome arrays following treatment for 7 days with PBS, latex beads, wild type myelin or Plpl tg myelin, plus raw values in arbitrary units and normalised values (to positive control spots) for spot intensity for each of the cytokines assayed, plus a template for cytokine array.

Figure 5 - scans of X-ray films and raw arbitrary unit values of band sizes and intensities.

Figure 6 and 7 - images from IN Cell Analyzer 2000 and CellProfiler values for myelin, axons and DAPI +ve nuclei.

Due the size of files for the microplate images these can not be provided but are available at request from the corresponding author(JE) julia.edgar@glasgow.ac.uk

\section{Software availability}

Analysis pipelines are available from Github: https:/github.com/ muecs/cp/tree/v1.0

An archived version available of the pipelines are available from Zenodo: http://doi.org/10.5281/zenodo.2533339 (Mücklisch \& Mücklisch, 2019)

Available under a 'Creative Commons Attribution 3.0 Unported License'

\section{Grant information}

This work was supported by the National Centre for the Replacement, Refinement and Reduction of Animals in Research (NC3Rs) [grant Ref. B004-13.1 to JE, ERK and CL] and the Multiple Sclerosis Society, UK [grant ref. 853 to JE and JTA; grant ref. 918 to JE, MM and JTA; and grant ref. 991 to JE and ERK].

The funders had no role in study design, data collection and analysis, decision to publish, or preparation of the manuscript.

\section{Acknowledgement}

A special mention goes to Duncan and Yvonne Booth and their 10 in10 event which raises fund for the Multiple Sclerosis Society, UK. We are grateful to Profs. Nigel Groome and Elior Peles for gifts of antibodies; to Professor Klaus-Armin Nave for transgenic animal lines Plpl transgenic (\#72) and Cnpl knockout; to Professor Robert Nibbs for helpful scientific discussion; and to Professor Kurt Anderson for access and training in live-imaging. 


\section{Supplementary material}

Detailed protocols are provided in the following Supplementary Files:

Supplementary File 1. Preparing mouse spinal cord cultures

Click here to access the data

Supplementary File 2. Preparing custom-made dishes for live imaging

\section{Click here to access the data}

Supplementary File 3. Preparing and labelling a myelin-enriched spinal cord fraction

Click here to access the data

Supplementary File 4. Immunostaining myelinating cell cultures

Click here to access the data

Supplementary File 5. Using CellProfiler analysis software

Click here to access the data

Supplementary Video 1: Live imaging of myelin phagocytosis

Click here to access the data

Allen NJ, Lyons DA: Glia as architects of central nervous system formation and function. Science. 2018; 362(6411): 181-185.

PubMed Abstract | Publisher Full Text | Free Full Text

Almeida RG: The Rules of Attraction in Central Nervous System Myelination.

Front Cell Neurosci. 2018; 12: 367.

PubMed Abstract | Publisher Full Text | Free Full Text

Almeida RG, Lyons DA: On Myelinated Axon Plasticity and Neuronal Circuit Formation and Function. J Neurosci. 2017; 37(42): 10023-10034.

PubMed Abstract | Publisher Full Text

Anderson TJ, Klugmann M, Thomson CE, et al:: Distinct phenotypes associated with increasing dosage of the PLP gene: implications for CMT1A due to PMP22 gene duplication. Ann NY Acad Sci. 1999; 883: 234-246.

PubMed Abstract | Publisher Full Text

Baker D, Amor S: Experimental autoimmune encephalomyelitis is a good model of multiple sclerosis if used wisely. Mult Scler Relat Disord. 2014; 3(5): 555-564. PubMed Abstract | Publisher Full Text

Barnett SC, Linington C: Myelination: do astrocytes play a role? Neuroscientist. 2013; 19(5): 442-50.

PubMed Abstract | Publisher Full Text

Barres BA, Hart IK, Coles HS, et al.: Cell death and control of cell survival in the oligodendrocyte lineage. Cell. 1992; 70(1): 31-46.

PubMed Abstract | Publisher Full Text

Barres BA, Raff MC: Control of oligodendrocyte number in the developing rat optic nerve. Neuron. 1994; 12(5): 935-942.

PubMed Abstract | Publisher Full Text

Bechler ME, Byrne L, Ffrench-Constant C: CNS Myelin Sheath Lengths Are an Intrinsic Property of Oligodendrocytes. Curr Biol. 2015; 25(18): 2411-2416.

PubMed Abstract | Publisher Full Text | Free Full Text

Beers DR, Henkel JS, Xiao Q, et al.: Wild-type microglia extend survival in PU.1

knockout mice with familial amyotrophic lateral sclerosis. Proc Natl Acad Sci U S A. 2006; 103(43): 16021-16026.

PubMed Abstract | Publisher Full Text | Free Full Text

Berghoff SA, Gerndt N, Winchenbach J, et al.: Dietary cholesterol promotes

repair of demyelinated lesions in the adult brain. Nat Commun. 2017; 8: 14241. PubMed Abstract | Publisher Full Text | Free Full Text

Bijland S, Thomson G, Euston M, et al:: Dataset 1 in: An in vitro model for studying CNS white matter: functional properties and experimental approaches. F1000Research. 2019.

http://www.doi.org/10.5256/f1000research.16802.d233269

Boillée S, Yamanaka K, Lobsiger CS, et al:: Onset and progression in inherited ALS determined by motor neurons and microglia. Science. 2006; 312(5778): 1389-1392.

PubMed Abstract | Publisher Full Text

Bottenstein JE, Sato GH: Growth of a rat neuroblastoma cell line in serum-free supplemented medium. Proc Natl Acad Sci U S A. 1979; 76(1): 514-517. PubMed Abstract | Publisher Full Text | Free Full Text

Bsibsi M, Ravid R, Gveric D, et al.: Broad expression of Toll-like receptors in the human central nervous system. J Neuropathol Exp Neurol. 2002; 61(11): 1013-1021.

PubMed Abstract | Publisher Full Text

Cantoni C, Bollman B, Licastro D, et al.: TREM2 regulates microglial cell activation in response to demyelination in vivo. Acta Neuropathol. 2015; 129(3): 429-447.

PubMed Abstract | Publisher Full Text | Free Full Text

Carpenter AE, Jones TR, Lamprecht MR, et al:: CellProfiler: image analysis software for identifying and quantifying cell phenotypes. Genome Biol. 2006; 7(10): R100

PubMed Abstract | Publisher Full Text | Free Full Text

Chang A, Nishiyama A, Peterson J, et al.: NG2-positive oligodendrocyte progenitor cells in adult human brain and multiple sclerosis lesions. J Neurosci. 2000; 20(17): 6404-6412.

PubMed Abstract | Publisher Full Text

Chang A, Tourtellotte WW, Rudick R, et al.: Premyelinating oligodendrocytes in chronic lesions of multiple sclerosis. N Engl J Med. 2002; 346(3): 165-173. PubMed Abstract | Publisher Full Text

Chow JC, Young DW, Golenbock DT, et al:: Toll-like receptor-4 mediates lipopolysaccharide-induced signal transduction. J Biol Chem. 1999; 274(16): 10689-10692.

PubMed Abstract | Publisher Full Text

Cotrina ML, Nedergaard M: Brain connexins in demyelinating diseases: therapeutic potential of glial targets. Brain Res. 2012; 1487: 61-68. PubMed Abstract | Publisher Full Text | Free Full Text

Crawford AH, Tripathi RB, Foerster S, et al.: Pre-Existing Mature Oligodendrocytes Do Not Contribute to Remyelination following Toxin-Induced Spinal Cord Demyelination. Am J Pathol. 2016; 186(3): 511-6. PubMed Abstract | Publisher Full Text | Free Full Text

Cumberworth SL, Barrie JA, Cunningham ME, et al.: Zika virus tropism and interactions in myelinating neural cell cultures: CNS cells and myelin are preferentially affected. Acta Neuropathol Commun. 2017; 5(1): 50.

PubMed Abstract | Publisher Full Text | Free Full Text

Davalos D, Grutzendler J, Yang G, et al:: ATP mediates rapid microglial response to local brain injury in vivo. Nat Neurosci. 2005; 8(6): 752-758.

PubMed Abstract | Publisher Full Text

Demerens C, Stankoff B, Logak M, et al.: Induction of myelination in the central nervous system by electrical activity. Proc Natl Acad Sci U S A. 1996; 93(18) 9887-9892.

PubMed Abstract | Publisher Full Text | Free Full Text

Deshmukh VA, Tardif V, Lyssiotis CA, et al:: A regenerative approach to the 
treatment of multiple sclerosis. Nature. 2013; 502(7471): 327-332. PubMed Abstract | Publisher Full Text | Free Full Text

Duncan ID, Brower A, Kondo Y, et al.: Extensive remyelination of the CNS leads to functional recovery. Proc Natl Acad Sci U S A. 2009; 106(16): 6832-6836. PubMed Abstract | Publisher Full Text | Free Full Text

Dutta DJ, Woo DH, Lee PR, et al:: Regulation of myelin structure and conduction velocity by perinodal astrocytes. Proc Natl Acad Sci U S A. 2018; 115(46): 11832-11837.

PubMed Abstract | Publisher Full Text | Free Full Text

Edgar JM, McCulloch MC, Montague P, et al.: Demyelination and axonal preservation in a transgenic mouse model of Pelizaeus-Merzbacher disease. EMBO Mol Med. 2010; 2(2): 42-50.

PubMed Abstract | Publisher Full Text | Free Full Text

Edgar JM, McCulloch MC, Thomson CE, et al:: Distribution of mitochondria along small-diameter myelinated central nervous system axons. J Neurosci Res. 2008; 86(10): 2250-2257.

PubMed Abstract | Publisher Full Tex

Edgar JM, McLaughlin M, Werner HB, et al.: Early ultrastructural defects of axons and axon-glia junctions in mice lacking expression of Cnp1. Glia. 2009; 57(16): 1815-1824.

PubMed Abstract | Publisher Full Tex

Edgar JM, McLaughlin M, Yool D, et al.: Oligodendroglial modulation of fast axonal transport in a mouse model of hereditary spastic paraplegia. $J$ Cell Biol. 2004; 166(1): 121-131.

PubMed Abstract | Publisher Full Text | Free Full Text

Fancy SP, Baranzini SE, Zhao C, et al.: Dysregulation of the Wnt pathway inhibits timely myelination and remyelination in the mammalian CNS. Genes Dev. 2009; 23(13): 1571-1585.

PubMed Abstract | Publisher Full Text | Free Full Text

Feng GP, Mellor RH, Bernstein M, et al.: Imaging neuronal subsets in transgenic mice expressing multiple spectral variants of GFP. Neuron. 2000; 28(1): 41-51. PubMed Abstract | Publisher Full Text

Forrester JV, McMenamin PG, Dando SJ: CNS infection and immune privilege. Nat Rev Neurosci. 2018; 19(11): 655-671.

PubMed Abstract | Publisher Full Text

Fowler JH, McQueen J, Holland PR, et al.: Dimethyl fumarate improves white matter function following severe hypoperfusion: Involvement of microglia/ macrophages and inflammatory mediators. J Cereb Blood Flow Metab. 2018; 38(8): 1354-1370.

PubMed Abstract | Publisher Full Text | Free Full Text

Franklin RJ, Ffrench-Constant C: Remyelination in the CNS: from biology to therapy. Nat Rev Neurosci. 2008; 9(11): 839-855.

PubMed Abstract | Publisher Full Text

Franklin RJ, ffrench-Constant C, Edgar JM, et al:: Neuroprotection and repair in multiple sclerosis. Nat Rev Neurol. 2012; 8(11): 624-634.

PubMed Abstract | Publisher Full Text

Froger N, Orellana JA, Calvo CF, et al.: Inhibition of cytokine-induced connexin43 hemichannel activity in astrocytes is neuroprotective. Mol Cell Neurosci. 2010; 45(1): 37-46.

PubMed Abstract | Publisher Full Tex

Fünfschilling U, Supplie LM, Mahad D, et al:: Glycolytic oligodendrocytes maintain myelin and long-term axonal integrity. Nature. 2012; 485(7399): 517-521. PubMed Abstract | Publisher Full Text | Free Full Text

George R, Griffin JW: Delayed macrophage responses and myelin clearance during Wallerian degeneration in the central nervous system: the dorsal radiculotomy model. Exp Neurol. 1994; 129(2): 225-236.

PubMed Abstract | Publisher Full Text

Gibson EM, Purger D, Mount CW, et al.: Neuronal activity promotes

oligodendrogenesis and adaptive myelination in the mammalian brain Science. 2014; 344(6183): 1252304

PubMed Abstract | Publisher Full Text | Free Full Text

Glass WG, Lim JK, Cholera R, et al:: Chemokine receptor CCR5 promotes leukocyte trafficking to the brain and survival in West Nile virus infection. $J$ Exp Med. 2005; 202(8): 1087-1098.

PubMed Abstract | Publisher Full Text | Free Full Text

Goebbels S, Wieser GL, Pieper A, et al:: A neuronal PI $(3,4,5) P$-dependent program of oligodendrocyte precursor recruitment and myelination. Nat Neurosci. 2017; 20(1): 10-15.

PubMed Abstract | Publisher Full Tex

Griffiths IR, Klugmann M, Anderson TJ, et al: Axonal swellings and degeneration in mice lacking the major proteolipid of myelin. Science. 1998; 280(5369): $1610-1613$

PubMed Abstract | Publisher Full Text

Grillner S, McClellan A, Sigvardt K, et al:: Activation of NMDA-receptors elicits "fictive locomotion" in lamprey spinal cord in vitro. Acta Physiol Scand 1981; 113(4): 549-551.

PubMed Abstract | Publisher Full Tex

Hall ED, Oostveen JA, Gurney ME: Relationship of microglial and astrocytic activation to disease onset and progression in a transgenic model of familial ALS. Glia 1998; 23(3): 249-256.

PubMed Abstract | Publisher Full Tex

Hanisch UK, Kettenmann $\mathrm{H}$ : Microglia: active sensor and versatile effector cells in the normal and pathologic brain. Nat Neurosci. 2007; 10(11): 1387-1394.

PubMed Abstract | Publisher Full Text
Hines DJ, Choi HB, Hines RM, et al.: Prevention of LPS-induced microglia activation, cytokine production and sickness behavior with TLR4 receptor interfering peptides. PLoS One. 2013; 8(3): e60388.

PubMed Abstract | Publisher Full Text | Free Full Text

Hines JH, Ravanelli AM, Schwindt R, et al:: Neuronal activity biases axon selection for myelination in vivo. Nat Neurosci. 2015; 18(5): 683-689. PubMed Abstract | Publisher Full Text | Free Full Text

Honda S, Sasaki Y, Ohsawa K, et al.: Extracellular ATP or ADP induce chemotaxis of cultured microglia through $\mathrm{G}_{\mathrm{H} / 0}$-coupled $\mathrm{P} 2 \mathrm{Y}$ receptors.

$J$ Neurosci. 2001; 21(6): 1975-1982.

PubMed Abstract | Publisher Full Text

Huang JK, Jarjour AA, Nait Oumesmar B, et al.: Retinoid X receptor gamma signaling accelerates CNS remyelination. Nat Neurosci. 2011; 14(1): 45-53. PubMed Abstract | Publisher Full Text | Free Full Text

Hughes CE, Nibbs RJB: A guide to chemokines and their receptors. FEBS J. 2018; 285(16): 2944-2971.

PubMed Abstract | Publisher Full Text | Free Full Text

loannidou K, Anderson KI, Strachan D, et al:: Time-lapse imaging of the dynamics of CNS glial-axonal interactions in vitro and ex vivo. PLOS One. 2012; 7(1): e30775

PubMed Abstract | Publisher Full Text | Free Full Text

Ip CW, Kroner A, Bendszus M, et al.: Immune cells contribute to myelin degeneration and axonopathic changes in mice overexpressing proteolipid protein in oligodendrocytes. J Neurosci. 2006; 26(31): 8206-8216.

PubMed Abstract | Publisher Full Text

Ip CW, Kroner A, Crocker PR, et al:: Sialoadhesin deficiency ameliorates myelin degeneration and axonopathic changes in the CNS of PLP overexpressing mice. Neurobiol Dis. 2007; 25(1): 105-111.

PubMed Abstract | Publisher Full Text

Irvine KA, Blakemore WF: Remyelination protects axons from demyelinationassociated axon degeneration. Brain. 2008; 131(Pt 6): 1464-1477.

PubMed Abstract | Publisher Full Text

Ishibashi T, Dakin KA, Stevens B, et al.: Astrocytes promote myelination in response to electrical impulses. Neuron. 2006; 49(6): 823-832.

PubMed Abstract | Publisher Full Text | Free Full Text

Kassmann CM, Lappe-Siefke C, Baes M, et al:: Axonal loss and neuroinflammation caused by peroxisome-deficient oligodendrocytes. Nat Genet. 2007; 39(8): 969-976.

PubMed Abstract | Publisher Full Text

Keirstead HS, Blakemore WF: Identification of post-mitotic oligodendrocytes incapable of remyelination within the demyelinated adult spinal cord.

J Neuropath Exp Neurol. 1997; 56(11): 1191-1201.

PubMed Abstract | Publisher Full Tex

Kigerl KA, de Rivero Vaccari JP, Dietrich WD, et al.: Pattern recognition receptors and central nervous system repair. Exp Neurol. 2014; 258: 5-16.

PubMed Abstract | Publisher Full Text | Free Full Text

Kirkpatrick LL, Witt AS, Payne HR, et al:: Changes in microtubule stability and density in myelin-deficient shiverer mouse CNS axons. J Neurosci. 2001; 21(7): 2288-2297.

PubMed Abstract | Publisher Full Tex

Kline D: Quantitative microinjection of mouse oocytes and eggs.

Microinjections: Methods and application. (Carroll DJ, ed), Humana Press. 2009;

518: $135-156$

PubMed Abstract | Publisher Full Text

Kotter MR, Zhao C, van Rooijen N, et al:: Macrophage-depletion induced impairment of experimental CNS remyelination is associated with a reduced oligodendrocyte progenitor cell response and altered growth factor expression. Neurobiol Dis. 2005; 18(1): 166-175.

PubMed Abstract | Publisher Full Text

Lampron A, Larochelle A, Laflamme N, et al:: Inefficient clearance of myelin debris by microglia impairs remyelinating processes. J Exp Med. 2015; 212(4) 481-495.

PubMed Abstract | Publisher Full Text | Free Full Text

Lappe-Siefke C, Goebbels S, Gravel M, et al.: Disruption of Cnp1 uncouples oligodendroglial functions in axonal support and myelination. Nat Genet. 2003; 33(3): 366-374

PubMed Abstract

Lee PR, Cohen JE, lacobas DA, et al:: Gene networks activated by specific patterns of action potentials in dorsal root ganglia neurons. Sci Rep. 2017; 7: 43765.

PubMed Abstract | Publisher Full Text | Free Full Text

Lee S, Leach MK, Redmond SA, et al.: A culture system to study oligodendrocyte myelination processes using engineered nanofibers. Nat Methods. 2012a; 9(9): 917-922.

PubMed Abstract | Publisher Full Text | Free Full Text

Lee Y, Morrison BM, Li Y, et al.: Oligodendroglia metabolically support axons and contribute to neurodegeneration. Nature. 2012b; 487(7408): 443-448. PubMed Abstract | Publisher Full Text | Free Full Text

Lennartz M, Drake J: Molecular mechanisms of macrophage Toll-like receptorFc receptor synergy [version 1; referees: 2 approved]. F1000Res. 2018;

7(F1000 Faculty Rev): 21

PubMed Abstract | Publisher Full Text | Free Full Text

Lindner M, Thümmler K, Arthur A, et al.: Fibroblast growth factor signalling in multiple sclerosis: inhibition of myelination and induction of pro-inflammatory environment by FGF9. Brain. 2015; 138(Pt 7): 1875-1893.

PubMed Abstract | Publisher Full Text 
Liu MT, Chen BP, Oertel P, et al.: The T cell chemoattractant IFN-inducible protein 10 is essential in host defense against viral-induced neurologic disease. J Immunol. 2000; 165(5): 2327-2330.

PubMed Abstract | Publisher Full Text

Lobo-Silva D, Carriche GM, Castro AG, et al:: Balancing the immune response in the brain: IL-10 and its regulation. J Neuroinflammation. 2016; 13(1): 297. PubMed Abstract | Publisher Full Text | Free Full Text

Lopez de Armentia M, Jancic D, Olivares R, et al:: cAMP response elementbinding protein-mediated gene expression increases the intrinsic excitability of CA1 pyramidal neurons. J Neurosci. 2007; 27(50): 13909-13918.

PubMed Abstract | Publisher Full Text

Lundgaard I, Luzhynskaya A, Stockley JH, et al.: Neuregulin and BDNF induce a switch to NMDA receptor-dependent myelination by oligodendrocytes. PLOS Biol. 2013; 11(12): e1001743.

PubMed Abstract | Publisher Full Text | Free Full Text

Madhavan M, Nevin ZS, Shick HE, et al.: Induction of myelinating oligodendrocytes in human cortical spheroids. Nat Methods. 2018; 15(9): 700-706.

PubMed Abstract | Publisher Full Text

Mayoral SR, Etxeberria A, Shen YA, et al:: Initiation of CNS Myelination in the Optic Nerve Is Dependent on Axon Caliber. Cell Rep. 2018; 25(3): 544-550.e3. PubMed Abstract | Publisher Full Text | Free Full Text

Mei F, Fancy SPJ, Shen YA, et al:: Micropillar arrays as a high-throughput screening platform for therapeutics in multiple sclerosis. Nat Med. 2014; 20(8): 954-960.

PubMed Abstract | Publisher Full Text | Free Full Text

Mei F, Lehmann-Horn K, Shen YA, et al:: Accelerated remyelination during inflammatory demyelination prevents axonal loss and improves functional recovery. eLife. 2016; 5: pii: e18246.

PubMed Abstract | Publisher Full Text | Free Full Text

Mensch S, Baraban M, Almeida R, et al.: Synaptic vesicle release regulates myelin sheath number of individual oligodendrocytes in vivo. Nat Neurosci. 2015; 18(5): 628-630.

PubMed Abstract | Publisher Full Text | Free Full Text

Meyer N, Richter N, Fan Z, et al:: Oligodendrocytes in the Mouse Corpus Callosum Maintain Axonal Function by Delivery of Glucose. Cell Rep. 2018; 22(9): 2383-2394.

PubMed Abstract | Publisher Full Tex

Mir F, Le Breton GC: A novel nuclear signaling pathway for thromboxane A2 receptors in oligodendrocytes: evidence for signaling compartmentalization during differentiation. Mol Cell Biol. 2008; 28(20): 6329-6341.

PubMed Abstract | Publisher Full Text | Free Full Text

Miron VE, Boyd A, Zhao JW, et al:: M2 microglia and macrophages drive oligodendrocyte differentiation during CNS remyelination. Nat Neurosci. 2013; 16(9): 1211-1218.

PubMed Abstract | Publisher Full Text | Free Full Text

Mitew S, Gobius I, Fenlon LR, et al.: Pharmacogenetic stimulation of neuronal activity increases myelination in an axon-specific manner. Nat Commun. 2018 9(1): 306.

PubMed Abstract | Publisher Full Text | Free Full Text

Mücklisch S, Mücklisch K (nee Thümmler): muecs/cp v1.0. 2019.

http://www.doi.org/10.5281/zenodo.2533339

Nagai M, Re DB, Nagata T, et al.: Astrocytes expressing ALS-linked mutated

SOD1 release factors selectively toxic to motor neurons. Nat Neurosci. 2007; 10(5): 615-622.

PubMed Abstract | Publisher Full Text | Free Full Text

Najm FJ, Madhavan M, Zaremba A, et al: Drug-based modulation of endogenous stem cells promotes functional remyelination in vivo. Nature. 2015; 522(7555): 216-20

PubMed Abstract | Publisher Full Text | Free Full Text

Napoli I, Neumann H: Microglial clearance function in health and disease.

Neuroscience. 2009; 158(3): 1030-1038.

PubMed Abstract | Publisher Full Text

Nave KA, Trapp BD: Axon-glial signaling and the glial support of axon function. Annu Rev Neurosci. 2008; 31: 535-561.

PubMed Abstract | Publisher Full Text

Nave KA, Griffiths IR: Models of Pelizaeus-Merzbacher disease. In: Myelin biology and disorders (Lazzarini RA, Griffin JW, Lassmann H, Nave K-A, Miller RH, Trapp

BD, eds), Amsterdam: Elsevier. Amsterdam: Elsevier, 2004; 2: 1125-1142.

Publisher Full Text

Neumann H, Kotter MR, Franklin RJ: Debris clearance by microglia: an essentia link between degeneration and regeneration. Brain. 2009; 132(Pt 2): 288-295. PubMed Abstract | Publisher Full Text | Free Full Text

Nimmerjahn A, Kirchhoff F, Helmchen F: Resting microglial cells are highly dynamic surveillants of brain parenchyma in vivo. Science. 2005; 308(5726) 1314-1318.

PubMed Abstract | Publisher Full Text

Norton WT, Poduslo SE: Myelination in rat brain: method of myelin isolation.

J Neurochem. 1973; 21(4): 749-757.

PubMed Abstract | Publisher Full Text

Pan B, Fromholt SE, Hess EJ, et al.: Myelin-associated glycoprotein and complementary axonal ligands, gangliosides, mediate axon stability in the CNS and PNS: neuropathology and behavioral deficits in single- and doublenull mice. Exp Neurol. 2005; 195(1): 208-217.

PubMed Abstract | Publisher Full Text | Free Full Text

Patani R, Balaratnam M, Vora A, et al:: Remyelination can be extensive in multiple sclerosis despite a long disease course. Neuropathol Appl Neurobiol. 2007; 33(3): 277-287.

PubMed Abstract | Publisher Full Text

Perry VH, Hume DA, Gordon S: Immunohistochemical localization of macrophages and microglia in the adult and developing mouse brain. Neuroscience. 1985; 15(2): 313-326.

PubMed Abstract | Publisher Full Text

Poliani PL, Wang Y, Fontana E, et al:: TREM2 sustains microglial expansion during aging and response to demyelination. J Clin Invest. 2015; 125(5): 2161-2170.

PubMed Abstract | Publisher Full Text | Free Full Text

Readhead C, Schneider A, Griffiths IR, et al.: Premature arrest of myelin formation in transgenic mice with increased proteolipid protein gene dosage. Neuron. 1994; 12(3): 583-595.

PubMed Abstract | Publisher Full Text

Saijo K, Glass CK: Microglial cell origin and phenotypes in health and disease. Nat Rev Immunol. 2011; 11(11): 775-787.

PubMed Abstract | Publisher Full Text

Sánchez-Gómez MV, Serrano MP, Alberdi E, et al:: Isolation, Expansion, and Maturation of Oligodendrocyte Lineage Cells Obtained from Rat Neonatal Brain and Optic Nerve. Methods Mol Biol. 2018; 1791: 95-113.

PubMed Abstract | Publisher Full Text

Schirmer L, Möbius W, Zhao C, et al: Oligodendrocyte-encoded Kir4.1 function is required for axonal integrity. eLife. 2018; 7: pii: e36428.

PubMed Abstract | Publisher Full Text | Free Full Text

Scolding N, Franklin R, Stevens S, et al: Oligodendrocyte progenitors are present in the normal adult human CNS and in the lesions of multiple sclerosis. Brain. 1998; 121(Pt 12): 2221-2228.

PubMed Abstract

Shen S, Sandoval J, Swiss VA, et al:: Age-dependent epigenetic control of differentiation inhibitors is critical for remyelination efficiency. Nat Neurosci. 2008; 11(9): 1024-1034.

PubMed Abstract | Publisher Full Text | Free Full Text

Sierra A, Abiega O, Shahraz A, et al.: Janus-faced microglia: beneficial and detrimental consequences of microglial phagocytosis. Front Cell Neurosci. 2013; 7 : 6.

PubMed Abstract | Publisher Full Text | Free Full Text

Song L, Pei L, Yao S, et al:: NLRP3 Inflammasome in Neurological Diseases, from Functions to Therapies. Front Cell Neurosci. 2017; 11: 63.

PubMed Abstract | Publisher Full Text | Free Full Text

Song WM, Colonna M: The identity and function of microglia in

neurodegeneration. Nat Immunol. 2018a; 19(10): 1048-1058.

PubMed Abstract | Publisher Full Text

Song WM, Colonna M: The Microglial Response to Neurodegenerative Disease. Adv Immunol. 2018b: 139: 1-50.

PubMed Abstract | Publisher Full Text

Sorensen EW, Lian J, Ozga AJ, et al:: CXCL10 stabilizes T cell-brain endothelial cell adhesion leading to the induction of cerebral malaria. JCl Insight. 2018; 3(8): pii: 98911.

PubMed Abstract | Publisher Full Text | Free Full Text

Tambuyzer BR, Ponsaerts P, Nouwen EJ: Microglia: gatekeepers of central nervous system immunology. J Leukoc Biol. 2009; 85(3): 352-370.

PubMed Abstract | Publisher Full Text

Thion MS, Ginhoux F, Garel S: Microglia and early brain development: An intimate journey. Science. 2018; 362(6411): 185-189.

PubMed Abstract | Publisher Full Tex

Thomson CE, Griffiths IR, McCulloch MC, et al.: In vitro studies of axonallyregulated Schwann cell genes during Wallerian degeneration. $J$ Neurocytol. 1993; 22(8): 590-602.

PubMed Abstract | Publisher Full Text

Thomson CE, Hunter AM, Griffiths IR, et al:: Murine spinal cord explants: a model for evaluating axonal growth and myelination in vitro. J Neurosci Res. 2006; 84(8): 1703-1715.

PubMed Abstract | Publisher Full Text

Thomson CE, McCulloch M, Sorenson A, et al:: Myelinated, synapsing cultures of murine spinal cord--validation as an in vitro model of the central nervous system. Eur J Neurosci. 2008; 28(8): 1518-1535.

PubMed Abstract | Publisher Full Text | Free Full Text

Trapp BD, Bernier L, Andrews SB, et al:: Cellular and subcellular distribution of 2',3'-cyclic nucleotide 3'-phosphodiesterase and its mRNA in the rat central nervous system. $J$ Neurochem. 1988; 51(3): 859-868.

PubMed Abstract | Publisher Full Tex

Trapp BD, Nave KA: Multiple sclerosis: an immune or neurodegenerative disorder? Annu Rev Neurosci. 2008; 31: 247-269.

PubMed Abstract | Publisher Full Text

van Zundert B, Brown RH Jr: Silencing strategies for therapy of SOD1-mediated 
ALS. Neurosci Lett. 2017; 636: 32-39.

PubMed Abstract | Publisher Full Text

Wake H, Lee PR, Fields RD: Control of local protein synthesis and initial events in myelination by action potentials. Science. 2011; 333(6049): 1647-1651.

PubMed Abstract | Publisher Full Text | Free Full Text

Wlodarczyk A, Holtman IR, Krueger M, et al:: A novel microglial subset plays a key

role in myelinogenesis in developing brain. EMBO J. 2017; 36(22): 3292-3308.

PubMed Abstract | Publisher Full Text | Free Full Text

World Health Organization: Atlas multiple sclerosis resources in the world 2008. Geneva: WHO Press; 2008.

Reference Source

Yamanaka K, Chun SJ, Boillee S, et al.: Astrocytes as determinants of disease progression in inherited amyotrophic lateral sclerosis. Nat Neurosci. 2008 11(3): 251-253.

PubMed Abstract | Publisher Full Text | Free Full Text

Zalc B, Fields RD: Do Action Potentials Regulate Myelination? Neuroscientist.
2000; 6(1): 5-13

PubMed Abstract | Publisher Full Text | Free Full Text

Zawadzka M, Rivers LE, Fancy SP, et al:: CNS-resident glial progenitor/stem cells produce Schwann cells as well as oligodendrocytes during repair of CNS demyelination. Cell Stem Cell. 2010; 6(6): 578-590.

PubMed Abstract | Publisher Full Text | Free Full Text

Zhang Y, Chen K, Sloan SA, et al:: An RNA-sequencing transcriptome and splicing database of glia, neurons, and vascular cells of the cerebral cortex. J Neurosci. 2014; 34(36): 11929-11947.

PubMed Abstract | Publisher Full Text | Free Full Text

Zhang $\mathrm{H}$, Jarjour $\mathrm{AA}$, Boyd $\mathrm{A}$, et al:: Central nervous system remyelination in culture--a tool for multiple sclerosis research. Exp Neurol. 2011; 230(1): 138-148. PubMed Abstract | Publisher Full Text | Free Full Text

Zheng M, Tao W, Zou Y, et al: Nanotechnology-Based Strategies for siRNA Brain Delivery for Disease Therapy. Trends Biotechnol. 2018; 36(5): 562-575. PubMed Abstract | Publisher Full Text 


\section{Open Peer Review}

\section{Current Peer Review Status:}

\section{Version 1}

Reviewer Report 19 February 2019

https://doi.org/10.5256/f1000research.18368.r43885

(C) 2019 Trotter J. This is an open access peer review report distributed under the terms of the Creative Commons Attribution License, which permits unrestricted use, distribution, and reproduction in any medium, provided the original work is properly cited.

\section{Jacqueline Trotter}

Department of Biology, Molecular Cell Biology, Institute of Developmental Biology and Neurobiology, Johannes Gutenberg University of Mainz, Mainz, Germany

This article expands in substantial detail on a previously published method of myelinating cultures generated from murine spinal cord. The authors clearly demonstrate that establishing the cultures on MEA chips facilitates the monitoring of electrophysiological properties of the system. They show clearly the manipulation of gene expression in the culture using siRNA and also the ability to study developmental and pathological processes, such as innate immune responses, using imaging. They also demonstrate the use of multi-well plates facilitating drug screening.

The article thus describes an excellent straightforward method to complement, and in some instances replace, experiments in live animals. The method will be very useful for screening reagents with the potential to influence myelination or remyelination. It therefore provides a timely and important contribution to the experimental toolbox of myelin researchers.

Are a suitable application and appropriate end-users identified?

Yes

If applicable, is the statistical analysis and its interpretation appropriate? Yes

Are the 3Rs implications of the work described accurately? Yes

Is the rationale for developing the new method (or application) clearly explained? Yes

Is the description of the method technically sound?

Yes

Are sufficient details provided to allow replication of the method development and its use 
by others?

Yes

If any results are presented, are all the source data underlying the results available to ensure full reproducibility?

Yes

Are the conclusions about the method and its performance adequately supported by the findings presented in the article?

Yes

Competing Interests: No competing interests were disclosed.

Reviewer Expertise: Myelination, primary cell culture, siRNA

I confirm that I have read this submission and believe that I have an appropriate level of expertise to confirm that it is of an acceptable scientific standard.

Author Response 19 Feb 2019

Julia Edgar

We are very grateful to reviewer for taking the time to carefully read and consider our manuscript, which became rather long in the end.

Competing Interests: None

Reviewer Report 14 February 2019

https://doi.org/10.5256/f1000research.18368.r43736

(c) 2019 Newman T. This is an open access peer review report distributed under the terms of the Creative Commons Attribution License, which permits unrestricted use, distribution, and reproduction in any medium, provided the original work is properly cited.

\section{Tracey A. Newman}

Southampton Neuroscience Group, Institute for Life Sciences, Centre for Biological Sciences, University of Southampton, Southampton, UK

The disease burden associated with nervous system white matter (myelin) changes is significant. Newer imaging modalities/image analyses are enabling the detection of white matter changes in the clinic. The upshot of this is that there is a need for robust systems for the study of the mechanisms underlying demyelination/dysmyelination and systems in which to study remyelination. A significant amount of the research to address these issues relies on the use of invivo rodent experiments. Many of which fall into the moderate category of in-vivo procedure at a minimum. This work describes a relatively straight-forward model system which could replace, or 
be used to inform, some of the in-vivo work.

The rationale is clear and the methods are thoroughly described. The description and interpretation of the data is robust, and the suggested utility of the method is proportionate. The manuscript would be improved further by considering the following:

1. A short section describing similar/or equivalent in-vitro systems ideally describing the advantage of the system described.

2. Clarification regarding the value of having a system that is not part of a whole system (in the research highlights this is presented as a strength, but why is not made explicit).

3. The cultures have been exploited for a number of features, and this is supported by the data that is presented - however some analysis of the cellular organisation (2D/3D) of the cultures and the variability in this would be very useful as other researchers consider whether the system is appropriate for the experimental questions that want to address using the culture. It would also enable the myelination to be seen in a different orientation, and support the data described. One approach to this would be to section the cultures, possibly using an en-face approach as the cultures are grown on coverslips. This approach has been used in other organoid/mini-brain culture analyses.

4. A key issue with the development of new methods is the dissemination to other groups, the authors report that the model could be readily adopted in other labs equipped for cell culture. Has this happened? Irrespective of whether the model has been used to test a hypothesis elsewhere, it would be useful to know that a second group working from the protocols has reported similar findings, this will increase confidence in the model.

5. Re the methods, describe briefly the sterilisation step for the live imaging dishes.

6. Minor points a careful final proof-read is needed e.g. flurobite p5 needs to be corrected.

Are a suitable application and appropriate end-users identified?

Yes

If applicable, is the statistical analysis and its interpretation appropriate?

Yes

Are the 3Rs implications of the work described accurately?

Yes

Is the rationale for developing the new method (or application) clearly explained?

Yes

Is the description of the method technically sound?

Yes

Are sufficient details provided to allow replication of the method development and its use by others?

Yes

If any results are presented, are all the source data underlying the results available to ensure full reproducibility? 
Yes

Are the conclusions about the method and its performance adequately supported by the findings presented in the article?

Partly

Competing Interests: No competing interests were disclosed.

Reviewer Expertise: Referee suggested by the NC3Rs for their scientific expertise and experience in assessing $3 R$ s impact

I confirm that I have read this submission and believe that I have an appropriate level of expertise to confirm that it is of an acceptable scientific standard.

Author Response 19 Feb 2019

Julia Edgar

We are very grateful to the reviewer for taking the time to carefully read and consider the manuscript and will respond more fully to her comments shortly.

Competing Interests: None

The benefits of publishing with F1000Research:

- Your article is published within days, with no editorial bias

- You can publish traditional articles, null/negative results, case reports, data notes and more

- The peer review process is transparent and collaborative

- Your article is indexed in PubMed after passing peer review

- Dedicated customer support at every stage

For pre-submission enquiries, contact research@f1000.com 